\title{
The Pliocene Lillo, Poederlee, Merksplas, Mol and Kieseloolite Formations in northern Belgium: a synthesis
}

\author{
STEPHEN LOUWYE $^{1 *}$, JEF DECKERS ${ }^{2} \&$ NOËL VANDENBERGHE ${ }^{3}$ \\ 1 Paleontology and Paleoenvironment, Department of Geology, Ghent University, Krijgslaan 281/S8, Ghent, Belgium; \\ stephen.louwye@ugent.be. \\ ${ }^{2}$ VITO, Flemish Institute for Technological Research, Boeretang 200, Mol, Belgium; jef.deckers@vito.be. \\ ${ }^{3}$ Department Earth and Environmental Sciences, KU Leuven, Belgium; noel.vandenberghe@kuleuven.be. \\ corresponding author.
}

ABSTRACT. The Pliocene of Belgium subcrops in the northern part of the country and for more than a century has been the subject of many palaeontological and stratigraphical studies thanks to numerous temporary excavations that became accessible during the civil works for the expansion of the Antwerp Harbour. It was only during subsurface mapping from the 1980s onwards, in combination with cored and geophysical logged drillings, that these data became integrated which has led to new stratigraphical insights. The data relating to the current stratigraphy have now been inventoried, assessed, synthesized and a refined stratigraphical framework and correlation scheme is presented.

KEYWORDS: Neogene, lithostratigraphy, biostratigraphy, depositional environment, palaeogeography.

\section{Introduction}

During the Pliocene the North Sea Basin was a semi-enclosed basin and connection with the Atlantic Ocean existed only via the North (Ziegler, 1990) since the southern connection was impeded by the Weald-Artois Axis. However, Dearing Crampton-Flood et al. (2020) advance the concept that during high sea levels temporary connections may have existed, deduced from palaeontological data (Funnel, 1996) and sealevel evolution (Gibbard \& Lewin, 2016). The Pliocene North Sea Basin was a shallow shelf sea with depths not exceeding $100 \mathrm{~m}$ (Overeem et al., 2001). The Belgian Pliocene was deposited at the very southern edge of the basin and is characterised by shallow to marginal marine and even fluviatile depositional environments, hampering the lateral correlation between different units. The Pliocene in Belgium is restricted to its northern part in the Antwerp Harbour area and the Antwerp and Limburg Campine areas (Fig. 1).

The end of Miocene times saw a global sea-level drop related to a glacial period set between $6.26 \mathrm{Ma}$ and 5.50 Ma (Hodell et al., 2001) and according to Braga \& Martin (1996) the sea-level fall was in the range of tens of metres. During the early Pliocene Zanclean stage northern Belgium remained mainly above water and only limited sedimentation took place in the western area resulting in the shallow marine Kattendijk Formation (see Deckers \& Louwye, 2020, this volume) and the shelly Luchtbal Member of the Lillo Formation. By the end of the Zanclean and during the succeeding Piacenzian stage marine sedimentation in northwest Belgium resumed with the main part of the Lillo Formation and the Poederlee Formation, while in the eastern part of the Campine area the fluviatile Mol Formation was deposited. The eustatic evolution over the whole Pliocene shows a slightly falling sea-level trend (Hardenbol et al., 1998; Miller et al., 2005), while two globally recognizable glacial events occurred during the early Pliocene at circa 4.9-4.8 Ma and at circa $4.0 \mathrm{Ma}$, with additional glacial events at the early to middle Pliocene transition (circa 3.6 Ma) and also at 3.3 Ma (Marine Isotope Stage M2; De Schepper et al., 2014). Based on a multi-proxy analysis of a cored borehole in the western Netherlands, Dearing Crampton-Flood et al. (2018) postulate continental air temperatures during the early Pliocene of circa $12-14{ }^{\circ} \mathrm{C}$ and $10.5-12{ }^{\circ} \mathrm{C}$ during the mid-Pliocene. Utescher et al. (2012, fig. 9) published a Neogene Mean Annual Temperature curve based on the macroflora of the Lower Rhine Basin and showed the occurrence of several distinct cool phases during the Zanclean.
There is a considerable hiatus between the base of the Pliocene deposits and the underlying strata: the Pliocene rests in the Antwerp area unconformably on the lower-middle Miocene Berchem Formation and the Rupelian Boom Clay Formation, and in the Campine area on the upper Miocene Diest Formation and Kasterlee Formation. A considerable step forward in the stabilization of the Pliocene stratigraphy of northern Belgium was made by De Meuter \& Laga (1976) who reviewed and formally (re-)defined the lithostratigraphy. The Pliocene of northern Belgium consists of the Kattendijk, Lillo, Poederlee, Mol, Merksplas and Kieseloolite Formations that were later redescribed in a review of the Neogene formations by Laga et al. (2001; see Fig. 5 herein for a lithostratigraphic overview). Until the beginning of the last century, the Pliocene of northern Belgium was only known from temporary and small outcrops. However, knowledge of the sandy Pliocene deposits north of Antwerp expanded significantly through the numerous large temporary outcrops that became available during the construction of docks and sluices in the Antwerp Harbour area. The aim of this review is to systematically assemble the scattered and sometimes disparate data and information relating to the stratigraphy and palaeogeography of the Pliocene strata in North Belgium, and also to formulate recommendations for improving lithostratigraphic nomenclature and hierarchy. Note that the oldest Pliocene formation, the Kattendijk Formation, is discussed in a separate paper (Deckers \& Louwye, 2020, this volume) as is a Cone Penetration Testing approach to the stratigraphy of the Lillo Formation (Deckers et al., 2020, this volume)

\section{Lillo Formation}

The full historical development of the stratigraphic nomenclature is beyond the scope of this paper that concentrates on the presently used lithostratigraphic classification of the units distinguished within the Lillo Formation. The complexity of the historical evolution of the nomenclature in the Belgian Pliocene, and the Neogene in general, has several reasons. Among the most salient are the more than 150 years of continuously improving the dataset, the endemic fossils that do not allow correlations outside the basin, the relatively late introduction of the concept of lithostratigraphy as different from chronostratigraphy, the lack of stratigraphic stability at the level of ages and even epochs with strongly shifting definitions of the boundaries between Miocene, Pliocene, and Pleistocene and, finally, the variable meaning of certain stage names as for 
example 'Scaldisien'. Therefore, in the following sections the current nomenclature is defined and each time afterwards some brief related historical information is given. For more extensive information on the history of the Pliocene stratigraphic nomenclature in Belgium the reader is referred to Laga (1972) and De Meuter \& Laga (1976).

\subsection{The definition of the Lillo Formation}

De Meuter \& Laga (1976) formally defined the Lillo Formation as a shelly sand with a clayey admixture in the lower part and with several distinct shell layers. The colour is grey, grey-brown to light grey-brown. A gradual decrease of the clay occurs in the upper part of the formation, which is also devoid of shell layers. The type locality is to the north of the city of Antwerp in the Lillo district, where the former eponymous village disappeared during the construction works of two docks. The type section was visible in a temporary outcrop during the digging of the Tunnel-Canal Dock, later called the Tijsmans Tunnel (DOV BGD015W0304), at between $3 \mathrm{~m}$ and $23.5 \mathrm{~m}$ depth (Fig. 1, Table 1, see Fig. 2 for location of the Tijsmans Tunnel). The formation is further divided, from base to top, into the Luchtbal Member, the Oorderen Member, the Kruisschans Member, the Merksem Member and the Zandvliet Member. De Meuter \& Laga (1976) stressed the fact that whereas only the lower Luchtbal Member has distinct boundaries, a gradual change is observed between all other members. Moreover, the typical facies of the Kruisschans Member is often not recognised in the Antwerp Harbour area. The definition of the formation was re-iterated in a stratigraphical review of the Neogene of Belgium by Laga et al. (2001).

Glauconite content is fairly constant in the different members of the Lillo Formation and varies between 6 and $12 \%$ with some higher content up to $20 \%$ in the Luchtbal Member (Laga et al., 2015). Geets \& De Breuck (1991) made a comprehensive study of the heavy mineral content of the Lillo Formation. For the Oorderen, Kruisschans and Merksem Members the very stable minerals, including tourmaline, represent about half of the heavy mineral content, the garnets $15-20 \%$, the epidote and hornblende each $10-15 \%$ and the parametamorphics 5-7\%. Remarkably in the uppermost unit, the Zandvliet Member, the heavy mineral content changes strongly with less than $25 \%$ very stable minerals of which half are tourmaline, only $10 \%$ garnet and $10 \%$ epidote, $7 \%$ parametamorphics and in strikingly $42 \%$ hornblende.

The deposits now grouped in the Lillo Formation were first mentioned by Dumont (1850) and called 'Scaldisien'. The stage comprised the upper part of the fossiliferous sand north of Antwerp. Cogels (1874) discussed the molluscs recovered from the unit and moved it to the 'Scaldisien supérieur'. De Heinzelin (1955) included the deposits in the upper part of a Pliocene 'Scaldisien' stage and distinguished within the deposits the 'Horizon du Luchtbal' and the 'Horizon de Kallo'; the latter is equivalent to the present-day Oorderen Member. The present-day Kruisschans and Merksem Members, and probably also the Zandvliet Member, were placed within the Pleistocene 'Merxemien'.

\subsection{Present lithostratigraphic subdivision of the Lillo Formation}

\subsubsection{The Luchtbal Member}

The Luchtbal Member was formally redefined by De Meuter \& Laga (1976) as a light brown-grey to whitish, glauconitic sand with abundant well-preserved shells. Pseudomussium gerardi is conspicuously present, together with the polychaete ichnofossil Ditrupa, bryozoans and echinoderm spines. The type locality is the neighbourhood Luchtbal north of Antwerp and east of the harbour (Fig. 1, Table 1), while the type section of the member lies in the Second and Third harbour Docks, situated west of the Luchtbal district, between $10 \mathrm{~m}$ and $8 \mathrm{~m}$ below the natural land surface. The thickness is a maximum of $2 \mathrm{~m}$. In the Tunnel-Canal Dock type-section of the Lillo Formation, the member outcropped from $21.20 \mathrm{~m}$ to $23.50 \mathrm{~m}$ depth (Fig. 1, Table 1). De Meuter \& Laga (1976) stressed the irregular thickness of the unit, maximum $2 \mathrm{~m}$ to absent, and its patchy occurrence in the type area. However, thicknesses of up to $10 \mathrm{~m}$ are noted in the Campine area north of Antwerp (see profiles http://collections.naturalsciences.be/ssh-geology/ geology/profiles-neogeen2020). The Luchtbal Member rests unconformably on the subjacent Kattendijk Formation north of Antwerp. Buffel et al. (2001) recorded reworked molluscs from the Luchtbal Member in the southern part of the Antwerp Campine area and concluded that the Luchtbal crag extended into the Campine area to the east and was reworked before the deposition of the Poederlee Formation (see Section 3). Wesselingh et al. (2020, this volume) have reported the presence of a thin nodule-containing layer, the Broechem unit, with a specific mollusc content and within a lithology different from Kattendijk Formation below and from the units in the Lillo Formation above. These nodules also occur reworked at the base of the Lillo Formation.

Leriche (1912) was the first author to observe this unit in an excavation near Antwerp and described it as a grey-white sand at the base of the 'Scaldisien'. Later, Leriche (1927) described the base of the 'Scaldisien' as a whitish shelly sand deposited in a calm environment. A more formal definition was provided by de Heinzelin (1955) as 'Horizon du Luchtbal' as the lowest unit of his 'Assise inférieure' in the Pliocene 'Scaldisien' stage.

\subsubsection{The Oorderen Member}

The Oorderen Member was introduced by De Meuter \& Laga (1976) and was described as a fine-grained, glauconitic shelly unit with three conspicuous thick shell layers (see also Marquet, 2004). The lowest shell layer has at the base a gravel layer with rounded bones. This basal shell layer always has a typical undulating character ('allure en guirlande'; Tavernier $\&$ de Heinzelin, 1962, p. 19). Imbricated shells are steeply dipping parallel to the flanks of the wavy base of the shell layer (Deckers et al., 2020, fig. 4, this volume) and demonstrate a post-depositional origin of the undulation, probably a type of load cast. Also, other shell layers in the Oorderen Member show some undulation. A similar manifest undulation also occurs in a shell layer near the contact of the Kiel and Antwerp Members of the Miocene Berchem Formation (see Everaert et al., 2019, figs 6 and 7). In all cases the sediments just above the undulating shell layer are lying subhorizontal, pointing to a loading of the shell layer in the underlying sediment almost immediately after its deposition.

The lower sandy part of the unit holds three thick shell layers and is homogeneous grey-brown, while the clayey to very clayey upper part is darker grey (Goolaerts, 2000; Marquet, 2004; Laga et al., 2015). Characteristic molluscs from the Oorderen Member are Neptunea contraria, Angulus benedeni, Pinna pectinata and Scaphella lamberti. The type locality was Oorderen, a former village north of Antwerp. The type section of the member is between 13.5 and $10.5 \mathrm{~m}$ depth in the temporary outcrop of the Boudewijn Sluice (DOV kb7d15w-B282), and in the Lillo Formation type section in the Tunnel-Canal Dock between $15 \mathrm{~m}$ and $21 \mathrm{~m}$ depth (Fig. 1, Table 1). The Oorderen Member occurs both in the Antwerp Harbour area and more extensively to the north in the Campine area. South of Antwerp, where the Luchtbal Member is absent, the Oorderen Member rests directly on the early 


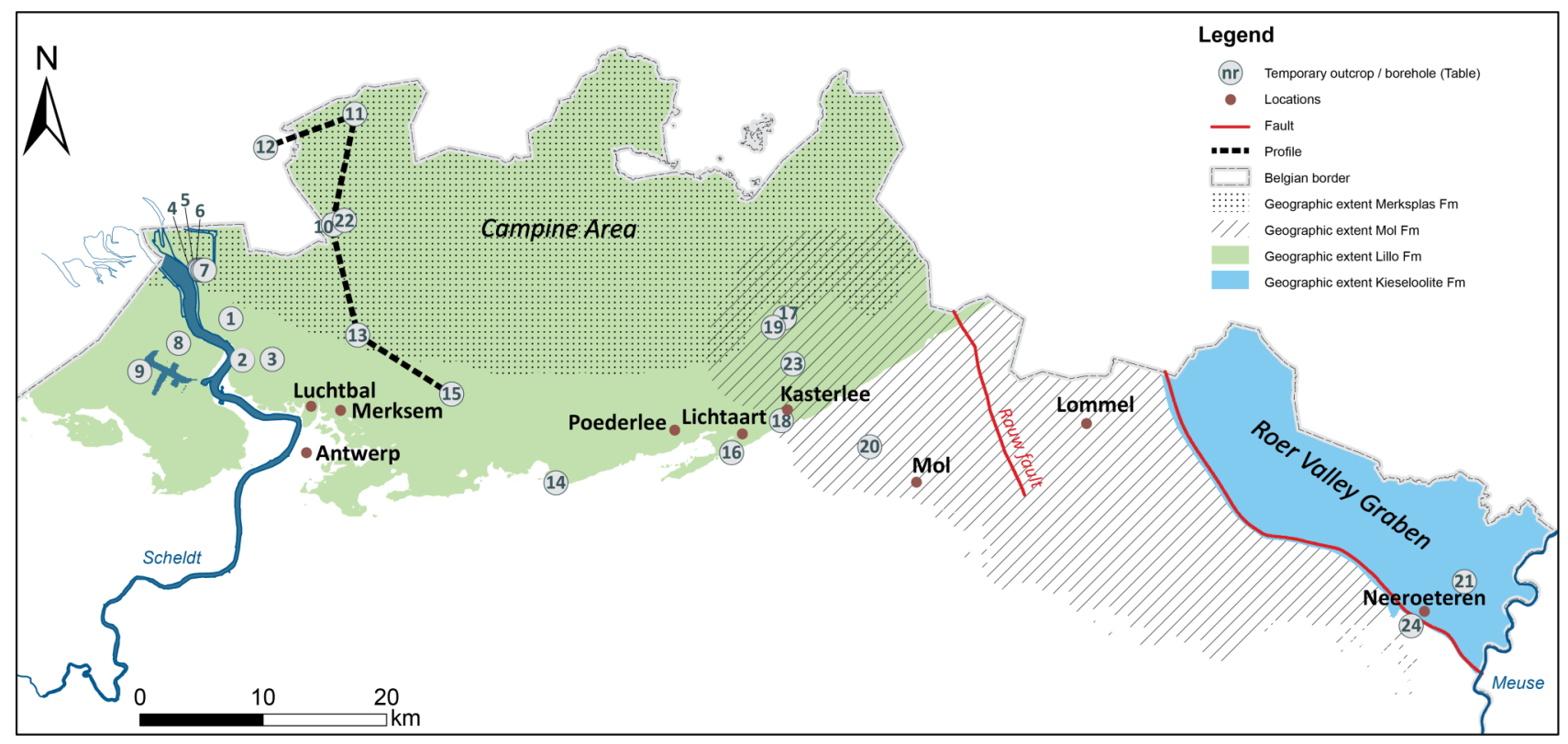

Figure 1. Location of bor eholes and outcrops (details in Table 1), and occurrence of Pliocene units.

Table 1. Overview of the boreholes and temporary outcrops together with the reference to the archives of the geological surveys (BGD: Geological Survey of Belgium; DOV: Databank Ondergrond Vlaanderen).

\begin{tabular}{|c|c|c|c|c|c|c|c|}
\hline Name & Code BGD & Code DOV & $\mathrm{Nr}$ & Name & Code BGD & Code DOV & $\mathrm{Nr}$ \\
\hline $\begin{array}{l}\text { temporary outcrop } \\
\text { Tijsmans Tunnel }\end{array}$ & 015W0304 & BGD015W0304 & 1 & Brasschaat borehole & 015E0270 & kb7d15e-B330 & 13 \\
\hline $\begin{array}{l}\text { temporary outcrop } \\
\text { Boudewijn Sluice }\end{array}$ & 015W0131 & kb7d15w-B282 & 2 & Grobbendonk outcrop & & TO-19970101 & 14 \\
\hline $\begin{array}{l}\text { temporary outcrop } \\
\text { Churchilldok }\end{array}$ & 015W0179 & kb7d15w-B285 & 3 & Schilde borehole & 029W0372 & kb16d29w-B390 & 15 \\
\hline $\begin{array}{l}\text { temporary outcrop } \\
\text { Zandvlietsluis }\end{array}$ & $014 \mathrm{E} 0153$ & GEO-79/205-A & 4 & $\begin{array}{l}\text { sand quarry Lichtaart - } \\
\text { Hoge Berg }\end{array}$ & & TO-19990101B & 16 \\
\hline $\begin{array}{l}\text { temporary outcrop } \\
\text { Zandvlietsluis }\end{array}$ & 014E0154 & GEO-79/205-B & 5 & Oud-Turnhout borehole & 017E0401 & kb8d17e-B497 & 17 \\
\hline $\begin{array}{l}\text { temporary outcrop } \\
\text { Zandvlietsluis }\end{array}$ & 014E0155 & GEO-79/205-C & 6 & $\begin{array}{l}\text { temporary outcrop N19g } \\
\text { Kasterlee }\end{array}$ & & TO-20120101 & 18 \\
\hline $\begin{array}{l}\text { temporary outcrop } \\
\text { Zandvlietsluis }\end{array}$ & 014E0156 & GEO-79/205-D & 7 & Turnhout borehole & 017E0398 & kb8d17e-B494 & 19 \\
\hline $\begin{array}{l}\text { temporary outcrop } \\
\text { Deurganckdok }\end{array}$ & & TO-19991001 & 8 & Mol SCK15 borehole & 031W0237 & $\mathrm{B} / 1-0158$ & 20 \\
\hline $\begin{array}{l}\text { temporary outcrop } \\
\text { Verrebroekdok }\end{array}$ & & TO-19990901 & 9 & Maaseik borehole & 049W0220 & $\mathrm{kb} 18 \mathrm{~d} 49 \mathrm{w}-\mathrm{B} 220$ & 21 \\
\hline Kalmthout borehole & 006Е0130 & kb7d6e-B155 & 10 & Kalmthout borehole & 006Е0089 & kb7d6e-B115 & 22 \\
\hline Essen borehole & 001E0044 & B/1-1095 & 11 & Kasterlee borehole & 017E0399 & kb8d17e-B495 & 23 \\
\hline $\begin{array}{l}\text { Huijbergen borehole } \\
\text { (B49G0204) }\end{array}$ & & & 12 & Quarry Oppitter & 064W0211 & kb26d64w-B217 & 24 \\
\hline
\end{tabular}

Pliocene Kattendijk Formation. De Meuter \& Laga (1976) noted that in boreholes the transitional boundary between the Oorderen Member and the overlying Kruisschans Member is not readily distinguished.

Cogels (1874) described the unit as 'Sables à Trophon antiquus', and it was later described by Mourlon (1880) as 'Sables à Fusus contraria' and by Halet (1935) as 'Sables à Neptunea contraria'. De Heinzelin (1955) finally included the 'Sables à Neptunea contraria' in his 'Horizon de Kallo' in the upper part ('Assise supérieure') of the Pliocene 'Scaldisien' stage, above the 'Horizon du Luchtbal'. The biofacies in the upper clayey part of the 'Horizon de Kallo' testifies of a gradual shallowing according to the latter author. The sedimentary cycle terminates with an emersion marked by the rather sporadic presence of the gastropod Melampus pyramidalis, a very discontinuous gravel bed and faunal and floral remains. De Heinzelin (1955) stressed the discontinuous character of the emersion deposits and states that these are more often recognised at the base of the superjacent deposits. Tavernier \& de Heinzelin (1962) repeated the regressive character in the upper part of the 'Sables de Kallo'.

The Austruweel sand is an informal name for a sandy unit with a limited occurrence north of Antwerp and characterised by the presence of the gastropod Melampus pyramidalis (Tavernier \& 
de Heinzelin, 1962; Laga, 1972).

\subsubsection{The Kruisschans Member}

The Kruisschans Member was formally redefined by De Meuter \& Laga (1976) as a grey-green, fine-grained to medium finegrained, locally coarse-grained, glauconitic sand with shell debris and abundant small shells. Many clay lenses and clay layers occur. The thickness of the clay layers varies between 1 to $1.5 \mathrm{~cm}$ but can sometimes reach $10 \mathrm{~cm}$ to $20 \mathrm{~cm}$. The lower part of the Kruisschans Member is strongly bioturbated. De Meuter \& Laga (1976) stated that no distinct boundary with the subjacent Oorderen Member is visible, but they do mention an occasional gravel at the base (see above). The clay intercalations become sparser in the upper part of the unit, and no distinct boundary with the superjacent Merksem Member can be observed. The type locality is Kruisschans near Antwerp, and the type section of the member was located in the temporary outcrop of the Boudewijn Sluice between $7.5 \mathrm{~m}$ and $5.5 \mathrm{~m}$ depth. In the type section of the Lillo Formation, the TunnelCanal Dock, the Kruisschans Member lies between $15 \mathrm{~m}$ and 12 $m$ depth (Fig. 1, Table 1). The distribution of this unit in the Antwerp Harbour area is patchy.

The Kruisschans Member was described for the first time as 'Sables argileux à Cardium parkinsoni et Nucella lapillus = Horizon du Kruisschans' by de Heinzelin (1955). He placed the 'Horizon du Kruisschans' above the boundary of the 'Scaldisien' in the base of the 'Merxemien' and considered it as a transgressive phase after the weak regression between the 'Scaldisien' and the 'Merxemien'. At that time, the boundary was thought to represent the Pliocene-Pleistocene boundary. At the Boudewijn Sluice de Heinzelin (1955) observed this distinct palaeontological boundary at a gravelly horizon that he considered exactly similar to the America Dock gravel described by earlier authors, e.g. Vincent (1889). Although Laga (1973, p. 22) reports that this gravel was not found at other locations since its description by de Heinzelin (1955), a closer examination of borehole descriptions has allowed confirmation of the more general presence of this America Dock gravel bed north of Antwerp (see Section 2.4.). Tavernier \& de Heinzelin (1962) considered the Kruisschans unit as the lower part of the 'Sables de Merksem' or the 'Merxemien' and deposited in a littoral environment. The latter authors reiterated the presence of a gravel bed, albeit discontinuous, and when absent the deposits appear continuous with the subjacent Oorderen Member.

\subsubsection{The Merksem Member}

The Merksem Member, redefined by De Meuter \& Laga (1976), is a grey-green fine-grained to medium fine-grained glauconitic sand. Coarse-grained sandy intercalations occur. The lower part of the unit is characterised by cross-bedded stratification and thin clay layers, while the upper part is horizontally to subhorizontally stratified with rare clay lenses. The bivalve Corbula gibba gibba is the characteristic fossil in this member. This bivalve is also associated with the Poederlee Formation (see Section 3.1.). Sandstone and siderite concretions have been observed. Tasselia ordamensis is a remarkable large petrified trace fossil (Van Tassel, 1964a, b), which, according to Olivero \& López Cabrera (2010), was produced by polychaetes. The type locality is the village Merksem near Antwerp, and the type section was in a temporary outcrop of a fortification at Merksem at $4.4 \mathrm{~m}$ depth. In the type section in the Tunnel-Canal Dock the member lies between $12 \mathrm{~m}$ and $3 \mathrm{~m}$ depth (Fig. 1, Table 1). The member does not crop out and was only identified in temporary outcrops in the harbour area north of Antwerp.

The Merksem Member was described for the first time in two malacological studies. Vanden Broeck \& Cogels (1877) called the unit 'Sables à Corbula striata de Merxem', while later
Vincent (1889) renamed the unit as 'Sables à Corbulomya complanata'. De Heinzelin (1955) discussed the previous observations and proposed the name 'Sables de Merxem' for the 'Sables gris à Aloides gibba abondante et Aloides complanata'. The latter author placed the unit, together with the 'Horizon de Kruisschans', stratigraphically above the 'Scaldisien' stage in the Pleistocene, and considered it a transgressive facies, albeit shallow marine, after the regressive facies observed at the top of the 'Scaldisien'. Tavernier \& de Heinzelin (1962) reaffirmed the Pleistocene age of the 'Sables de Merxem' or 'Merxemien' and placed the Pliocene-Quaternary boundary at the base of the unit.

\subsubsection{The Zandvliet Member}

The uppermost member of the Lillo Formation is the Zandvliet Member, introduced as a new member by De Meuter \& Laga (1976). The unit is described as a fine-grained, slightly clayey and glauconitic sand, horizontally stratified and with siderite concretions. The greater part of the unit is decalcified and holds no shells or shell debris, only the lowest part of the unit is calcareous and some shells occur. De Meuter \& Laga (1976) noted that the boundary with the subjacent Merksem Member is gradual and thus unclear: the Zandvliet Member is sometimes considered informally as the decalcified upper part of the Merksem Member. Indeed, in the Churchill Dock temporary outcrop (DOV kb7d15w-B285; Fig. 1, Table 1), de Heinzelin (1955) observed a decalcified facies of the Merksem Member that he considered strongly similar to his observations at Zandvliet.

The type locality is the village Zandvliet, located north of Antwerp. The type section was in a temporary outcrop for the construction of the Zandvliet Sluice (see link in caption of Fig. 2 for location) north of the city of Antwerp (BGD 014E0153, 014E0154, 014E0155, 014E0156; DOV GEO-79/205-A, GEO79/205-B, GEO-79/205-C, GEO-79/205-D; Fig. 1, Table 1). In outcrop, the unit is only known from temporary exposures north of Antwerp while it is logically accounting for the subsurface increase in thickness of the Lillo Formation to the north as observed on borehole logs. At the Zandvliet Sluice, north of the Tunnel-Canal Dock the thickness of the Merksem Member is reduced to half the thickness at the Tunnel-Canal Dock at the expense of the Zandvliet Member. This supports the assumption that the latter is a decalcified facies of the former (https:// collections.naturalsciences.be/ssh-geology-archives/boreholes/ profiles-boreholes/pgl/neogeen/PGL\%201980-217.jpg ).

\subsection{Biostratigraphic data}

The biostratigraphy of the Pliocene from northern Belgium has been extensively studied using calcareous microfossils. An extensive review of these studies has been published in a review compiled during the North Sea Basin IGCP Project 124 (Vinken, 1988).

Based on benthic foraminifers, De Meuter \& Laga (1976) defined the Cibicides labatulus acme Zone in the Luchtbal Member. The zone was named by Doppert et al. (1979) as the BFN5 zone, and later the equivalent upper Zanclean benthic foraminiferal Zone B11 was introduced by Willems et al. (1988). These zones were not recognised in the subjacent Kattendijk Formation nor in the superjacent Oorderen Member, but all point to an early Pliocene age. The Oorderen, Kruisschans and Merksem Members represent the Pliocene Elphidiella hannai - Cribrononion excavatum assemblage Zone (De Meuter \& Laga 1976), a zone redefined by Doppert et al. (1979) as BFN6. Willems et al. (1988) equated both latter zones to their benthic foraminiferal Zone B12, indicative of a Piacenzian to Pleistocene age.

Gadidae otoliths from the Lillo Formation were studied by Gaemers (1988) who recognised the upper Zanclean otolith 


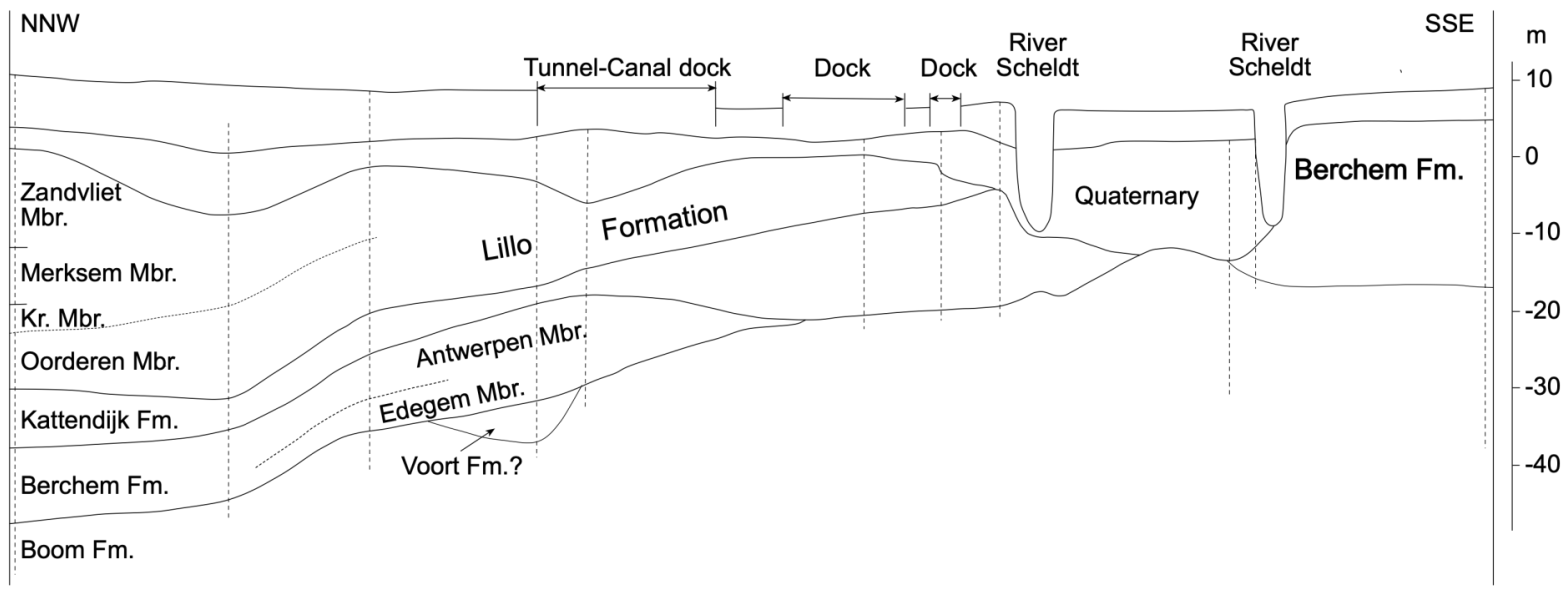

Figure 2. SSE-NNW cross section through the Antwerp area. Kr.: Kruisschans. Vertical dotted lines: boreholes, for details see: http:// collections.naturalsciences.be/ssh-geology/geology/profiles-neogeen2020/pgl-83-106.jpg/view.

Zone 18 in the Luchtbal Member and the lower Piacenzian Zone 19 in the Oorderen Member and 'younger' units. Hinsch (1988) recognised three benthic mollusc zones in the Lillo Formation, namely the middle Pliocene BM22A Zone in the Luchtbal Member, the middle Pliocene BM22B Zone in the Oorderen Member and the upper Pliocene BM22C Zone in the Kruisschans and Merksem Members. Janssen \& King (1988) placed the Luchtbal and the Oorderen Members in their lowerupper Pliocene pteropod Zone 22. According to Spiegler (2001) the Oorderen Member represents the Upper Bolboforma costairregularis Zone, corresponding to an age between $4.1 \mathrm{Ma}$ and 2.8 Ma. The mollusc fauna of the Pliocene in the Antwerp area has been revised in great details by Marquet (1993, 1998, 2002, 2004).

A preliminary and low-resolution study of the dinoflagellate cysts of the Lillo Formation was carried out in the Kalmthout well (BGD 006E0130, DOV kb7d6e-B155; Fig. 1, Table 1) by Louwye \& Laga (1998). The authors recognised the upper Zanclean to Lower Pleistocene Melitasphaeridium choanophorum Zone of Powell (1992). Louwye et al. (2004) did not observe either in the Deurganck Dock (DOV TO-19991001) nor in the Verrebroek Dock (DOV TO-19990901; Fig. 1, Table 1) the characteristic shelly sand of the Luchtbal Member as described by De Meuter \& Laga (1976), only a shelly layer of $1.4 \mathrm{~m}$ thick which Louwye et al. (2004) called a local 'basal shelly unit'. The lower part consisted of fine shell debris while the upper part consisted of densely packed entire shells. Louwye et al. (2004) regarded this basal shelly unit as a lag deposit belonging to the base of the Oorderen Member, with the shells reworked from the proper Luchtbal Member during the early stage of a transgression.

De Schepper et al. (2009) investigated the dinoflagellate cyst biostratigraphy of the Luchtbal Member in the TunnelCanal Dock, the stratotype for the Lillo Formation. The member does not contain biostratigraphical significant dinoflagellate cyst species, and De Schepper et al. (2009) suspected a taphonomical overprint in the dinoflagellate cyst assemblage through syn- or post-depositional oxidation and/or mechanical degradation. A possible age for the Luchtbal Member can only be inferred through the absence of Operculodinium tegillatum, a species with a highest occurrence in the latest Zanclean at 3.71 Ma. This species is abundant in the subjacent Kattendijk Formation and disappears abruptly at the upper boundary of the latter formation. The maximum age of the base of the Luchtbal
Member at around 3.71 Ma (latest Zanclean) is only partly in line with the late Zanclean age assessments provided by otoliths and benthic foraminiferal analyses (see above). However, De Schepper et al. (2009) correlate the base and the top of the Luchtbal Member with the sequence boundaries Za2 (4.04 Ma) and Pial (3.21 Ma) of Hardenbol et al. (1998), as was also done by Vandenberghe \& Hardenbol (1998, fig. 1). The dinoflagellate cyst Invertocysta lacrymosa disappears at the upper boundary of the Oorderen Member, and the calibrated highest occurrence at 2.74-2.72 Ma of the species in the north Atlantic Realm also defines the upper boundary of the eponymous Interval Zone RT5 of De Schepper \& Head (2009). Invertocysta lacrymosa is considered an open-marine species, and its sudden disappearance at the upper boundary of the Oorderen Member might be environmentally controlled, i.e., a shallower depositional environment for the overlying members. As a consequence, the Oorderen Member is not younger than 2.74-2.72 Ma (De Schepper et al., 2009).

The Kruisschans and Merksem Members hold no stratigraphic diagnostic dinoflagellate cyst species (De Schepper et al., 2009). The presence of thermophilic species such as Barssidinium spp. and Tectatodinium pellitum in both latter units is significant since they have not been reported in situ above the Pliocene-Early Pleistocene boundary at $2.58 \mathrm{Ma}$. A pre-Gelasian age, i.e., before the onset of the northern hemisphere glaciations, has thus been advanced (De Schepper et al., 2009). The pollen studies by Hacquaert $(1960,1962)$ could confirm a Reuverian B or pre-Gelasian age (de Jong, 1988). No biostratigraphic data is yet available for the Zandvliet Member.

\subsection{Characterisation on gamma ray - resistivity borehole logs}

No wireline log data is available near the type sections in the Antwerp Harbour. However, many Cone Penetration Test (CPTs) were carried out during the harbour expansion in the 20th and 21st centuries and allow correlations with the type sections (see also Deckers et al., 2020, this volume). To the east of the Antwerp Harbour or in the Campine area, the number of available CPTs decreases rapidly. In order to model the different members of the Lillo Formation in this area for the G3Dv3model of Flanders, Deckers et al. (2019) used predominantly wireline $\log$ data. The latter authors identified a typical threefold subdivision of the Lillo Formation in the western Campine area, hereafter called units Li-A, Li-B and Li-C. In the Kalmthout borehole (BGD 006E0130, DOV kb7d6e-B155; Fig. 1, Table 1, Fig. 
3), this threefold subdivision is very clearly expressed between the boundaries of the Lillo Formation (between 40 and $64 \mathrm{~m}$ depth).

Unit Li-A: The lower part of unit Li-A consists of relatively high resistivity and low gamma ray values that represent shellrich sands. The resistivity values increase from the subjacent Kattendijk Formation towards a maximum in the central part of unit Li-A, and then decrease again towards the top. The gamma ray values are lower compared to the Kattendijk Formation (except locally at the base) and generally decrease upwards in the lower part of unit Li-A, which coincides with a reduction in glauconite content.

Unit Li-B: Resistivity values reach a minimum in the central part or unit Li-B of the Lillo Formation. At this minimum of resistivity values, the gamma ray values are relatively high. These minimum resistivity and maximum gamma ray values coincide with clay enrichment (clay-rich sands and/or clay layers) in unit Li-B compared to the under- and overlying units $\mathrm{Li}-\mathrm{A}$ and Li-C. In the Huijbergen borehole the clay content of unit Li-B remains relatively low, but the grain size of this unit is markedly smaller than within units $\mathrm{A}$ and $\mathrm{C}$. From the minimum in unit Li-B, resistivity values gradually increase towards the upper part or unit $\mathrm{Li}-\mathrm{C}$ of the Lillo Formation.

Unit Li-C: Resistivity values generally increase upwards in unit $\mathrm{Li}-\mathrm{C}$, with a further increase at its top towards the superjacent Merkplas Formation. The gamma ray values on the contrary generally decrease from unit Li-B towards unit Li-C of the Lillo Formation. The increase in resistivity values and decrease in gamma ray values coincides with an increase in the grain size from unit $\mathrm{Li}-\mathrm{B}$ towards unit $\mathrm{Li}-\mathrm{C}$.

Based on a comparison with the Tunnel-Canal Dock, Deckers et al. (2019) correlated unit Li-A with the Luchtbal and Oorderen Members, unit Li-B with the Kruisschans Member and unit Li-C with the Merksem and Zandvliet Members. This correlation fits very well with the threefold subdivision of the Lillo Formation into units A, B and C based on CPTs near the Tunnel-Canal Dock section (Deckers et al., 2020, this volume). The latter authors, however, showed that the CPT-signature of the different members of the Lillo Formation, as defined in the Tunnel-Canal Dock section by Laga (1972), do no consistently correlate with the CPT-signature in the Boudewijn Sluice stratotypes of the Kruisschans and Oorderen Members as defined by De Meuter \& Laga (1976).

A north-south well-log correlation profile for the Lillo and Merksplas Formations across the western Campine area (Fig. 3) runs from the Schilde borehole in the southwestern Campine area in northern Belgium to the Huijbergen borehole in the southernmost Netherlands, just to the north of the Belgian border (Fig. 1, Table 1). The Huijbergen borehole was interpreted following the Belgian stratigraphy in this study. At about $77 \mathrm{~m}$ depth, the typical decrease in glauconite content and also a decrease in mica flakes from the Kattendijk Formation towards the Lillo Formation is observed and coincides with a subtle decrease in gamma ray values. The mollusc content sharply increases above the base of the Lillo Formation at $77 \mathrm{~m}$ depth. The $\mathrm{CaCO}_{3}$ content continues to increase upwards in the lower part of the latter formation. A gravel layer was observed in the highest $\mathrm{CaCO}_{3}$ zone at $70 \mathrm{~m}$ depth in the middle of the Lillo Formation. This layer could possibly correlate with the gravel layer that was described at the base of the Kruisschans Member in the America Dock (de Heinzelin, 1955 after Vincent, 1889 and Delheid, 1895) and the Boudewijn Sluice (de Heinzelin, 1952) temporary outcrops in the Antwerp Harbour. This gravel layer is not often observed in boreholes or in outcrops. As an example, the gravel layer was not observed either in the Churchill Dock (Fig. 1, Table 1) nor the TunnelCanal Dock temporary outcrops (Laga, 1972). Its presence in this area far to the north of the Antwerp Harbour, however, seems to indicate a regional importance.

The glauconite and $\mathrm{CaCO}_{3}$ content decreases, and organic matter increases above the gravel layer in the Huijbergen borehole. The gamma ray signal drops towards very low values and the mica content increases upwards at about $60 \mathrm{~m}$ depth. A few metres above the base of this low another gravel layer was noted. This layer coincides with a strong decrease in $\mathrm{CaCO}_{3}$ and mollusc content and is characteristic for the transition from the Lillo Formation towards the coarse quartz sand of the Merksplas Formation. Therefore, the gravel layer was interpreted as the basal gravel layer of the Merksplas Formation. This base is typically expressed in resistivity logs by the transition from an increase in unit $\mathrm{Li}-\mathrm{C}$ of the Lillo Formation towards a plateau of high resistivity values of the Merksplas Formation, as is clearly expressed in the Kalmthout borehole. The base of the Merksplas Formation in the latter borehole also coincides with an abrupt decrease in gamma ray values, which is not the case in the Huijbergen borehole nor in the Essen borehole. In the Huijbergen borehole, the top of the Merksplas Formation was interpreted at the subsequent gravel layer that coincides with a further upwards decrease in mollusc content and start of an upwards increase in gamma ray values.

From the Kalmthout borehole towards the Brasschaat borehole (BGD 015E0270, DOV kb7d15e-B330; Fig. 1, Table 1), units Li-A and Li-C seem to decrease in thickness. A similar decrease in thickness of CPT unit Li-A of the Lillo Formation was noted in the Antwerp Harbour area by Deckers et al. (2020, this volume) and Van Haren et al. (in prep.). The latter authors mention that just to the south of the Antwerp Harbour, CPT unit Li-A is absent as CPT unit Li-B directly overlies the Kattendijk Formation. The same situation was observed on the well-log correlation panel (Fig. 3), where unit Li-A has disappeared in the Schilde borehole and the high gamma ray values of unit $\mathrm{Li}$ B directly overly the Kattendijk Formation. The base of unit LiB consists here of a gravel layer. Further towards the southeast, the clayey unit Li-B probably coincides with the clayey unit in the Grobbendonk outcrop (DOV TO-19970101; Fig. 1, Table 1) studied by Vandenberghe et al. (2000). The latter authors interpreted the clayey unit as part of the Kruisschans Member, whereas based on a new interpretation of the stratigraphic range of dinoflagellate cyst species, De Schepper et al. (2009) later suggested a correlation of the same unit with the clayey upper part of the Oorderen Member.

Units B and C therefore appear to be more widespread than unit Li-A based on both CPTs, well logs and outcrop data. This might be in accordance with the pattern of regional transgression and deposition of the 'Merxemien' (now Kruisschans to Zandvliet Members) after regression in the uppermost 'Scaldisien' (now Kattendijk to Oorderen Members) as discussed by Tavernier \& de Heinzelin (1962). Based on similar mollusc findings, the latter authors presumed that the Poederlee Formation was deposited under the same transgression. Laga (1983) described in the Schilde borehole (BGD 029W0372, DOV kb16d29w-B390; Fig. 1, Table 1) at the level corresponding to the base of unit $\mathrm{Li}-\mathrm{B}$ in the present $\log$ interpretation, the occurrence of small flattened translucent quartz pebbles reminiscent of the typical Hukkelberg Gravel at the base of the Poederlee Formation. The lateral connection between the Lillo and Poederlee Formations is discussed in more detail in Section 3.1.

\subsection{Palaeoenvironmental interpretations}

Based on benthic foraminifera and bryozoans, Laga (1972) suggested deposition of the Luchtbal Member in a high-energy open marine environment with clear water and minimal sediment supply. The absence of protoperidinioid dinoflagellate cysts, i.e., taxa prone to oxidation and mechanical degradation 


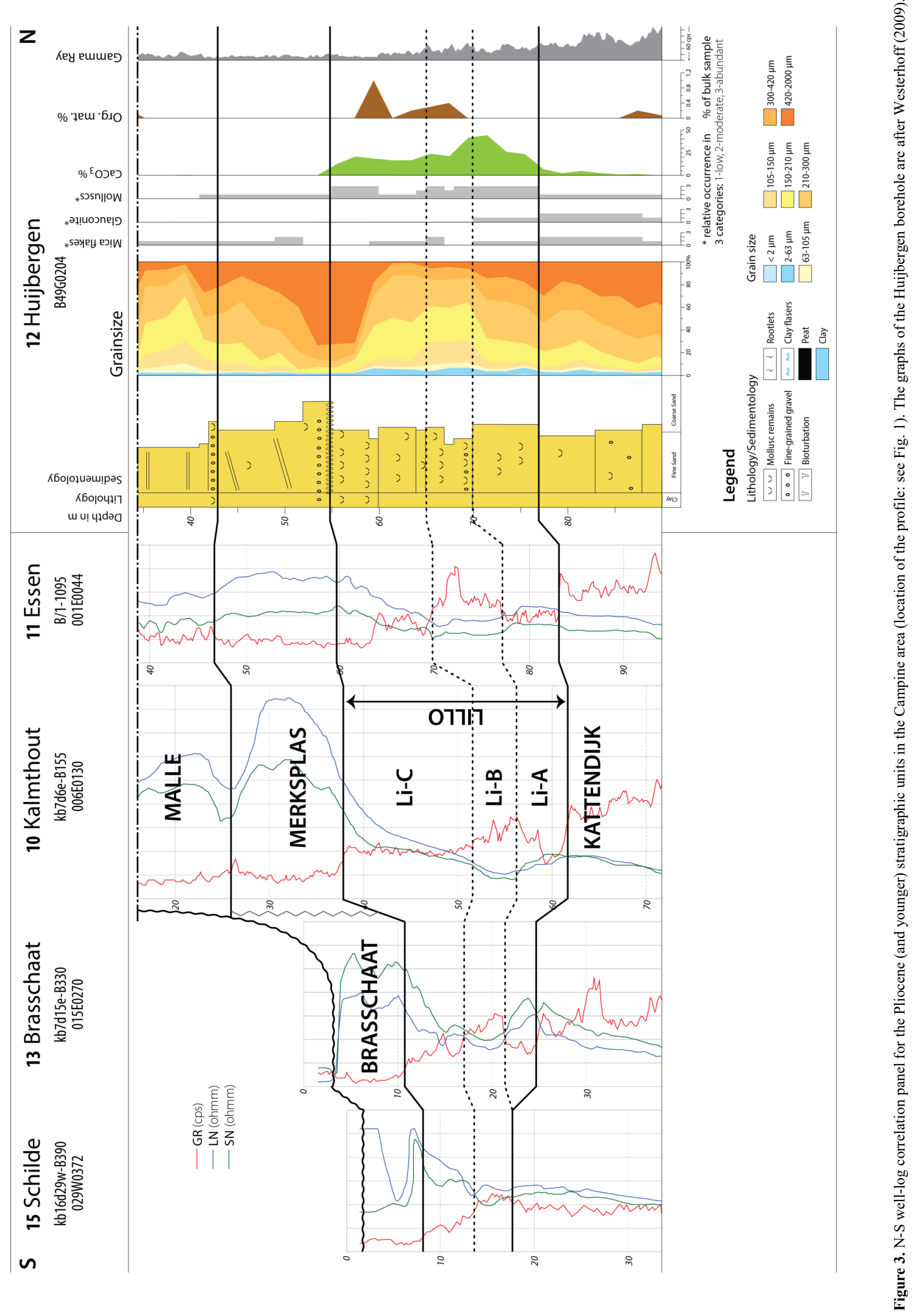


corroborate that suggestion and indicate a taphonomic overprint in the dinoflagellate cyst association (De Schepper et al., 2009). The latter authors furthermore interpret the Luchtbal Member as a lag deposit in response to a rising sea level and suggest that winnowing of palynomorphs and fine sediment in such environments is likely, resulting in the formation of tabular bodies of shells. The presence of the dinoflagellate cyst Filisphaera filifera points towards cool conditions.

Dinoflagellate cyst indices indicate a nearshore depositional environment for the Oorderen and Kruisschans Members (Louwye et al., 2004; De Schepper et al., 2009), especially at the base of the Oorderen Member and the top of the Kruisschans Member. Gaemers $(1975,1988)$ postulated deposition of the Oorderen Member in water depths between 10 to $20 \mathrm{~m}$, while Laga (1972), based on the benthic foraminiferal analysis, advocated a brackish influence in a calm, clear-water environment. The latter author also found evidence for higher energy conditions and more turbid waters higher in the Oorderen Member. Deposition of the Oorderen Member took place under warm-temperate conditions, rather comparable to the Kattendijk Formation (De Schepper et al., 2009). Invertocysta lacrymosa is considered as an open-marine species, and its sudden disappearance at the upper boundary of the Oorderen Member might be environmentally controlled, i.e. a shallower depositional environment of the overlying members.

The Kruisschans Member holds the highest average dinoflagellate cyst and pollen grain concentrations of the Lillo Formation together with a substantial clay fraction, both aspects indicative of a low-energy, nearshore depositional environment (De Schepper et al., 2009). These findings corroborate the statement by Laga (1972) who suggested deposition in shallow marine conditions with elevated turbidity and more euryhaline species, while Gaemers $(1975,1988)$ suggested a water depth of less than $10 \mathrm{~m}$ for the superjacent deposits of the Oorderen Member. Based on the abundance of erosive gullies and the cross-stratification of the infill of these small gullies, Gaemers (1988) concluded that the Kruisschans Member was deposited in a high energy, tidal environment in the Kallo outcrop. The latter interpretation conflicts with the findings of De Schepper et al. (2009) and Laga (1972) and might be related to differing lithostratigraphic interpretation of the Kruisschans Member at Kallo. Molluscs and fish remains in the Kruisschans Member point to a cool climate (Marquet, 1993; Vandenberghe et al., 2000).

The diversity of fossils is very low in the Merksem Member and entire shells are rather rare (de Heinzelin, 1950). The Merksem Member yields almost three times more pollen grains than marine palynomorphs and a high amount of plant debris (De Schepper et al., 2009). This observation, together with the low glauconite content and the presence of minute organic plant debris testifies to a rather nearshore depositional environment. Tavernier \& de Heinzelin (1962) supposed that the Merksem Member represented a beach deposit, under strong influence of wave and tidal actions. Based on his sedimentological and foraminiferal analyses, Laga (1972) also concluded that the Merksem Member represented a further shallowing of the depositional environment with important temperature and salinity fluctuations, progressively stronger wave actions and fluvial influence. The latter author presumed an estuarine depositional environment under tidal influence. In the absence of calcareous fossils and palynological data, no palaeoenvironmental analysis of the Zandvliet Member was made.

\section{Poederlee Formation}

\subsection{Lithological description and historical overview}

The Poederlee Formation was re-introduced by De Meuter \&
Laga (1976) for the deposits on hill tops near the village of Poederlee, some $30 \mathrm{~km}$ east of Antwerp (Fig. 1). The unit is defined as a fine-grained, slightly glauconitic unit with discrete lenses of clay in the base. The distinct basal Hukkelberg Gravel consists of discoidal, rounded quartz pebbles, flint and silicified carbonates (Gulinck, 1960). The upper part of the formation is oxidized in the type area, and sometimes limonitic sandstone with moulds of shells occurs (Geets, 1962). The stratotype for the Poederlee Formation is in the hills north of Poederlee village, which contain many iron-cemented sandstones. The distribution of the Poederlee Formation is limited to the centre of the Campine area, where it rests unconformably on the Miocene Kasterlee Formation and to the north it is covered by quartz sand of the Merksplas and Mol Formations (see Section 4.2.). The thickness of the Poederlee Formation is a maximum of $10 \mathrm{~m}$ (Schiltz et al., 1993).

Dumont was apparently the first to observe the sands of the Poederlee Formation during a mapping campaign in the hills around the village of Poederlee (Mourlon, 1882). Dumont assumed a correlation with the sands of the upper Miocene Diest Formation based on the ferruginous layers in the top of the formation. The first description of the unit was by Cogels \& Van Ertborn (1881) as 'la roche de Poederle' located north of Poederlee village. The molluscs were studied by Vincent (1889), but few lithological or stratigraphical data was provided although he introduced the name 'Poederlien'. The name 'étage Poederlien' was used on the 1:40 000 geological maps (see De Meuter \& Laga, 1976, table 1). De Heinzelin (1955) correlated the mollusc fauna from the 'Sables de Merxem' with the fauna recovered in the vicinity of Poederlee and Lichtaart, and thus at that time considered the deposits of the Poederlee Formation as Pleistocene. Gulinck (1960) detailed the gravel bed at the base of the formation and introduced the names Lichtaart and Hukkelberg (a hamlet near Poederlee) when describing the gravel bed. A large number of mollusc moulds in the limonitic sandstone were studied in great detail by Geets (1962) and indicated faunal similarities with the mollusc fauna from the Kruisschans Member, thus reconfirming the Pleistocene age of the unit supposed by de Heinzelin (1955). Geets (1962) and Tavernier \& de Heinzelin (1962) were the first to use formally the name Hukkelberg Gravel.

\subsection{Sedimentology and palaeoenvironmental interpretation}

The Poederlee Formation is a marine transgressive bioturbated sand occurring at the easternmost occurrence of the marine Lillo Formation. The underlying Hukkelberg Gravel is the beach component of the transgression. The discoidal shape of the pebbles shows a long-distance transport and the rates of flattening and roundness at different localities point to a transportation from the west. However, the composition of the gravel, which was studied in detail by Gulinck (1960), also contains silicified ooliths typical for the Kieseloolite Formation (see Section 4.3.) in the east and ultimately derived from northeastern France (Gullentops \& Huyghebaert, 1999). The sand is bioturbated and glauconite content is below 5\%, a lower content than the Lillo Formation (see Section 2.1.). In the Antwerp Campine area (see Fig. 5), a finer facies lacking glauconite is developed in top of the Poederlee Formation, the Heieinde facies (Buffel et al., 2001). The grain-size distribution of the Poederlee Formation is very well sorted with modal size between 175 and $200 \mu \mathrm{m}$ and fines $(<44 \mu \mathrm{m})$ content around $5 \%$ (Gullentops, 1963; Buffel et al., 2001). In the Lichtaart sand quarry Hoge Berg (DOV TO-19990101B; Fig. 1, Table 1), grain size, the presence of a few clay lenses together with deeper rill structures that originate from another gravel horizon $3 \mathrm{~m}$ above the Hukkelberg Gravel are indicative of limited tidal activity in near-coast deposits (Gullentops, 1963). 
The marine and terrestrial palynomorphs from the Poederlee Formation in the Oud-Turnhout borehole (BGD 017E 0401, DOV kb8d17e-B497; Fig. 1, Table 1) point to deposition in an inner neritic environment (Louwye \& De Schepper, 2010). The terrestrial palynomorphs outnumber the marine palynomorphs, and this is especially true in the upper part of the formation (i.e., the Heieinde facies). A nearshore depositional environment can thus be envisaged and possibly a shoaling phase during deposition of the upper part of the unit. The latter assumption is strengthened through the presence in the upper samples of freshwater palynomorphs (e.g., Pediastrum sp. indet., Debarya glyptosperma), indicative of river influence. Reworking of palynomorphs is also considerable and points towards increased erosion of the hinterland during deposition of the upper part of the unit.

Heavy mineral analysis points to a mixture of the marine and continental provinces (Edelman \& Doeglas, 1933; Verhaegen, 2020, this volume): aside $35-50 \%$ ubiquists including tourmaline, the marine group has $25-40 \%$ epidote and hornblende with only very minor garnet and the continental group has $15-30 \%$ parametamorphics dominated by staurolite, andalusite and kyanite (Geets, 1962). This parametamorphic group is more than double the content in the Lillo Formation. The grain size and heavy mineral content of the Poederlee Formation and the subjacent Kasterlee Formation sections at the Lichtaart sand quarry are remarkably similar, notwithstanding the hiatus of more than $1 \mathrm{Ma}$ (see Section 3.3.) between the two (Gullentops,1963; Geets,1962; Adriaens, 2015, Chapter VII). Adriaens (2015, Chapter VII) has explored the bulk and clay mineralogy of the transition between the late Miocene Kasterlee Formation and the Poederlee Formation in three locations near the Hukkelberg quarry TO-19630101, N19g Kasterlee (DOV TO-20120101, Rees borehole 017E0401; Fig. 1, Table 1). The latter author found different clay mineral compositions in the Poederlee Formation in each section, probably due to a combination of changing provenance with the start of the Poederlee Formation sedimentation and the reworking of underlying Kasterlee Formation sand locally weathered to Fevermiculite.

\subsection{Biostratigraphy}

Calcareous microfossils are absent in the Poederlee Formation because of (partial) decalcification and oxidation. However, organic-walled palynomorphs were successfully recovered by Louwye \& De Schepper (2010) from the Poederlee Formation in the Oud-Turnhout borehole in the northern Campine area. Based on the calibrated stratigraphic ranges of index dinoflagellate cyst species in the North Atlantic Realm, deposition of the Poederlee Formation took place between 3.71 Ma and 2.74-2.72 Ma (absence of Operculodinium tegillatum with a highest occurrence at $3.71 \mathrm{Ma}$, and the presence of Invertocysta lacrymosa with a highest occurrence at 2.74-2.72 Ma; Louwye \& De Schepper 2010). However, the Poederlee Formation could be older than $3.15 \mathrm{Ma}$ based on the (albeit rare) presence of Impagidiun solidum, a species with a calibrated range between 3.87 Ma and 3.15 Ma (De Schepper \& Head, 2008). The suggested and tentative age for the Poederlee Formation would then lie between 3.71 Ma and 3.15 Ma, a time interval that has to be considered as tentative (Louwye \& De Schepper 2010).

The recovered dinoflagellate cyst species from the Poederlee Formation allow a correlation with the Pliocene dinoflagellate cyst stratigraphy and biozonation by De Schepper $\&$ Head $(2008,2009)$ defined in the north Atlantic Realm. Both the Impagidinium solidum Interval Zone RT4, and the superjacent Invertocysta lacrymosa Interval Zone RT5 zone are recognised, albeit the lower boundary of RT4 and the upper boundary of RT5 cannot be identified in the Poederlee
Formation. The age inferred from the biozonation and the calibrated dinoflagellate cyst ranges is latest Zanclean to middle Piacenzian. Based on the ranges of calibrated dinoflagellate cyst species, and especially the overall character of the assemblage, a correlation with the Oorderen Member from the Lillo Formation is proposed by Louwye \& De Schepper (2010). This is in line with the correlation presented in Buffel et al. (2001, fig. 2) where the Oorderen shelly facies wedges out and occurs together with the upper part of the Poederlee Formation in borehole Vosselaar (017E0400), and the top of the Poederlee Formation in its type area is correlated with the base of the Merksem Member overlying Kruisschans Member based on the interpretation of the molluscs. Solely based on dinoflagellate cyst ranges, the hiatus between the Pliocene Poederlee Formation and the Miocene Kasterlee Formation in the Campine area (Oud-Turnhout borehole) is at least 1.61 Ma (Louwye \& De Schepper, 2010)

\subsection{Log characterization}

The Poederlee Formation was interpreted by Buffel et al. (2001) in the Oud-Turnhout borehole. The latter borehole lacks wireline $\operatorname{logs}$ but the nearby Turnhout borehole (BGD 017E0398, DOV kb8d17e-B494) does have wireline logs. Therefore, the stratigraphic interpretation of the Oud-Turnhout borehole can be projected on the wireline logs of the Turnhout borehole (Fig. 4). The Kasterlee Formation underlies the Poederlee Formation in these boreholes and is characterised by low resistivity and high gamma ray values due to its high clay and glauconite content. The base of the Poederlee Formation coincides with a subtle upwards decrease in gamma ray values and the start of an upwards increase in resistivity values. Gamma ray values remain rather uniform within the Poederlee Formation whereas resistivity values steadily increase throughout the unit. The increase in resistivity seems to coincide with a decrease in the percentage of the finest grain sizes $(<63$ $\mu \mathrm{m})$ as measured by Buffel et al. (2001) in the Oud-Turnhout borehole (Fig. 4). This coarsening upward agrees with the shallowing upward trend as established by the study of organicwalled palynomorphs of the Oud-Turnhout borehole by Louwye $\&$ De Schepper (2010). The Heieinde facies in the top of the Poederlee Formation is not expressed on log data. The upper boundary of the Poederlee Formation with the superjacent Schorvoort unit, a local facies of the Merksplas Formation (see Section 5), coincides with an abrupt upwards decrease in gamma ray values and increase in resistivity values, related to the latter's lower glauconite content and coarser grain size, respectively.

\section{Mol Formation}

\subsection{Stratigraphy: historical development and lithostratigraphic subdivisions}

The Mol Formation consists of white silica sand that was being extracted in the second half of the 19th century between the Campine towns of Mol and Lommel where it was discovered during the digging of the Campine canals (Fig. 1). Mourlon $(1898,1907)$ described and mapped the white quartz sand and discussed the stratigraphic position of the 'Sables de Moll' and proposed a correlation with either the 'Poederlien supérieur' or the Quaternary 'Amstelien'. Subsequent authors further discussed the geometry of the white sand body, its depositional environment and its stratigraphic position. A brief historical overview of these discussions on the stratigraphy of the Mol Formation is given in the explanatory notes for the 1:50 000 Geological Map Sheet $17 \mathrm{Mol}$ (Gullentops \& Vandenberghe, 1995a).

An important element for the stratigraphy of the Mol Formation is the presence of a lignite horizon in the sand that 


\section{Oud-Turnhout kb8d17e-B497 017 E0401}

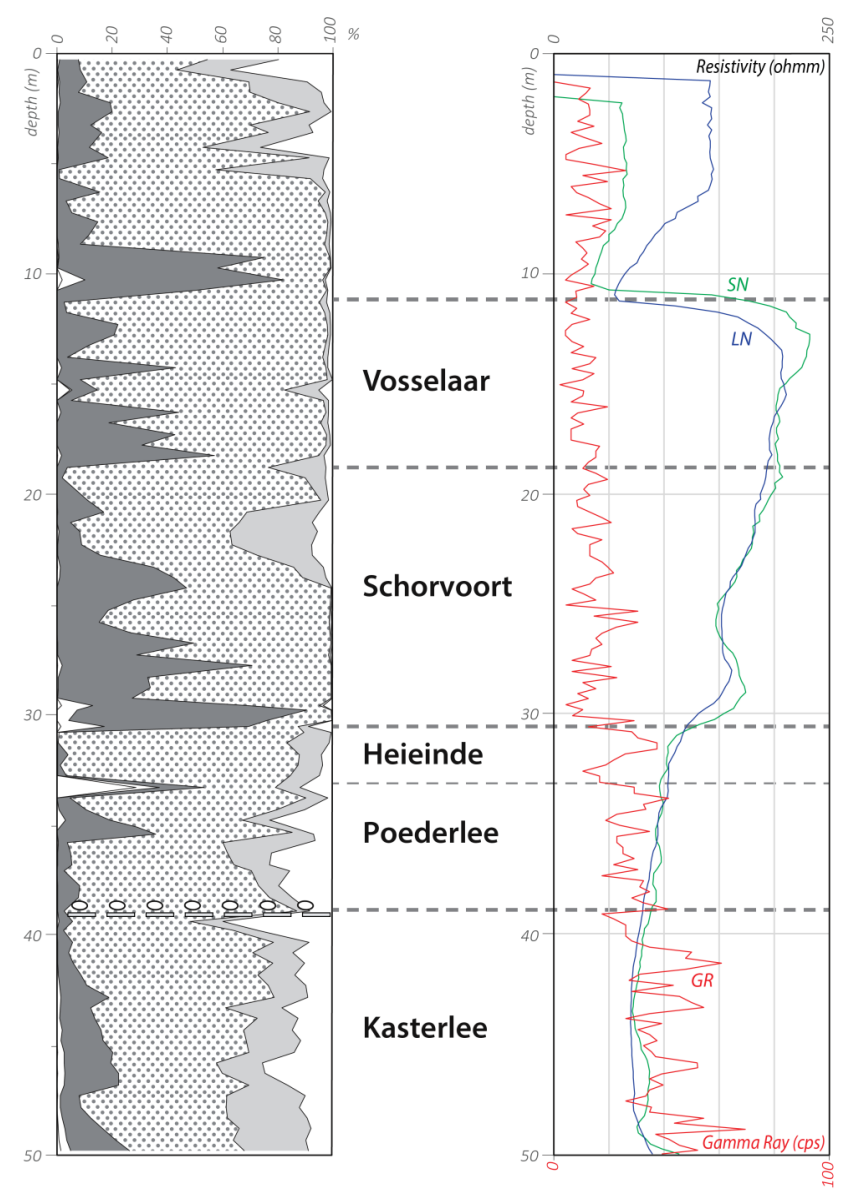

Legend:

$$
\begin{array}{ll}
\text { Legend: } & \text { Grain-size distribution } \\
\circ \text { Gravel } & 63-125 \mu \mathrm{m} \\
\square \text { Sandstone } & 125-250 \mu \mathrm{m}
\end{array}
$$

Figure 4. Projection of the stratigraphic interpretations (and grainsize analyses) of the Oud-Turnhout borehole according to Buffel et al. (2001) onto the wireline log of the nearby Turnhout borehole.

became exposed during public works along the Campine Canal around 1930. Later it allowed the recognition of the regionally important Rauw Fault and formed the basis for the present lithostratigraphic subdivision (Gullentops \& Vandenberghe, 1995a, b). Perhaps even more important is the palynological analysis that established a Reuver age for the Mol Formation, the regional upper Pliocene stage (Vanhoorne, 1962; Tavernier \& de Heinzelin, 1962; Vanhoorne, 1973). Other compositional elements in the Mol Formation for stratigraphic correlation are a Jurassic silicified crinoid (Leriche, 1913) and small silicified oolith pebbles (kieseloolites) allowing a lithostratigraphic correlation with the Kieseloolite Formation in the Roer Valley Graben (see Section 6, and Louwye \& Vandenberghe, 2020, this volume). At the base and at the top of the Donk Member of the Mol Formation (see Section 6) small discoidal, rounded quartz pebbles are observed (Gullentops \& Vandenberghe, 1995a; Gullentops \& Huyghebaert, 1999). These also occur concentrated at the base of the Poederlee Formation, where they are known as the Hukkelberg Gravel (see Section 3).

Gulinck (1962) recognised the difficulties of precisely defining and subdividing the Mol Formation and presented a WE oriented profile (Gulinck, 1962, fig. 3) across north Belgium showing the considerable increase in thickness towards the east and the continuous occurrence of the predominant lignite layer in about the middle of the sand package in the subsurface. As the strata are slightly dipping northeastwards, the lower part of the Mol Formation below the lignite is outcropping in the west and the westernmost near-surface occurrence of the lignite is now mapped between the Poppel and Rauw Faults (Gullentops \& Vandenberghe, 1995b). Gulinck (1962) reported that in the type area around Mol the coarser white sand of the typical Mol Formation overlays a fine sand with mica-containing clay lenses that was stippled with glauconite towards its base and of undetermined stratigraphic age. In fact, Gulinck (1962) was thereby referring to a sand that at the time he could not easily differentiate from the typical white silica sand of Mol above, nor define a precise boundary with it, and concluded that the meaning of the 'Sables de Mol' needed greater precision. Shortly afterwards, Gulinck et al. (1963) started to equate this fine underlying grey sand with the Kasterlee Formation although more to the west the latter was greenish and contained more glauconite. Presumably the geometric juxtaposition was considered more important than the lithological differences. The stratigraphic interpretation of boreholes by Gulinck and colleagues from the Geological Survey of Belgium in the Campine region systematically used this approach, as did done by Gulinck \& Laga (1975) in the classical cored and geophysically logged borehole at the Nuclear Research Centre in Mol (BGD 031W0237, DOV B/1-0158; Fig.1, Table 1). Obviously because of the lithological similarity with the overlying Mol Formation, borehole interpretations had difficulty in placing the boundary between these two units. Understandably but unfortunately, this has led to the common informal use of the term 'Mol inférieur' and 'Mol supérieur' in many borehole descriptions in the area, with 'Mol inférieur' used to describe sand that became less pure white quartz sand with small amounts of clay and glauconite giving a more greyish and even greenish rather than white colour to that sand. That practice should be abandoned as it is not accurate. Vandenberghe et al. (2020, this volume) have discussed this issue at length and gave lithological and borehole log criteria to make the distinction between the Mol Formation and the underlying unit. On the one hand respecting the tradition and literature initiated by Gulinck, and on the other hand recognizing the lithological similarity with the Mol Formation, Vandenberghe et al. (2020, this volume) used the term 'lower Mol' or 'Kasterlee-sensu-Gulinck' for this unit. For the time being the physical nature of the contact with the underlying clayey Kasterlee Formation is unclear: either a regionally important erosive contact representing a considerable hiatus, or just an intra-formational erosive contact only involving a minor hiatus. The dinoflagellate content of the 'lower Mol' or 'Kasterlee-sensu-Gulinck' points to the upper Miocene DN10 zone of de Verteuil \& Norris (1996) and the stratigraphic implications are discussed in Vandenberghe et al. (2020, this volume).

Whereas west of the Rauw Fault only the lower part of the Mol Formation is present, the total thickness of the formation increases east of it, where it can be divided into two parts, distinguished and separated by the continuous lignite layer discussed above. The lower part beneath the lignite is named the Donk Member of the Mol Formation and has a thickness of 10$25 \mathrm{~m}$ (Gullentops \& Vandenberghe, 1995a, b). Gullentops \& Huyghebaert (1999) reported the occurrence of Hukkelberg Gravel type discoidal, rounded quartz pebbles at the top of the Donk Member. The boundary with the underlying 'lower Mol' or 'Kasterlee-sensu-Gulinck' unit is based on the presence of a significant size fraction $>250 \mu \mathrm{m}$ in the Mol Formation while this fraction is lacking in the underlying grey sand (see Vandenberghe et al., 2020). Also, in some cases a coarser sand 
level, even with small dispersed pebbles is noted in boreholes at the base of the Donk Member. The gamma ray values are clearly higher in the underlying 'lower Mol' or 'Kasterlee-sensu-Gulinck' unit reflecting a marked finer grain size (Vandenberghe et al., 2020 figs $2 \& 5$, this volume). Around and to the east of the Rauw Fault a clayey zone with a thickness of a few metres is developed between the Donk Member of the classical Mol Formation and the underlying 'lower Mol' or 'Kasterlee-sensuGulinck' unit. In the same area, below this last unit another 20 $\mathrm{m}$ of grey sand occurs overlying the green glauconitic clayey sands of the clayey Kasterlee Formation. Not much is known about this sand unit; it has a slightly coarser grain-size distribution but also a slightly more elevated gamma ray signal and is stratigraphically unnamed.

The regionally continuous lignite horizon overlying the Donk Member is called the Maat Lignite Bed and the overlying white sand is called the Maatheide Member of the Mol Formation. This member can attain a thickness of $40 \mathrm{~m}$. It has been proposed by Gullentops \& Vandenberghe $(1995 \mathrm{a}$, b) that the upper boundary of the Maatheide Member should be defined by the occurrence of the Russendorp Lignite. However, this lignite layer is discontinuous and cannot be followed as a true stratigraphic marker in the area. The Russendorp Lignite also contains the Reuver flora (Gullentops \& Vandenberghe, 1995a).

\subsection{Depositional environment}

The sand of the Mol Formation is quarried by underwater extraction explaining the lack of a detailed sedimentological model for this deposit. As a consequence, the sand could be described in such diverse facies terms as fluviatile, estuarine and perimarine in Gullentops \& Wouters (1996, p. 21 \& p. 63). Nevertheless, the pure quartz composition and the presence of lignite leaves no doubt about the continental type depositional environment as already recognised by Tavernier \& de Heinzelin (1962). No shells were observed in the formation, no glauconite occurs and no dinoflagellate cysts could be recovered. The grain -size distribution is medium to well sorted and homogeneous, unlike fluviatile channel deposits. Still, occasionally oblique stratification was recognised (see e.g. Vandenberghe et al., 2020 , this volume, plate $1 \mathrm{D}$ ). The homogeneity of the Mol Formation in a broad area between Dessel and Lommel is confirmed by the Sibelco company production history (Vos, 2018, p. 154). The Donk Member has a modal grain size around $220 \mu \mathrm{m}$. Compared to the Donk Member the overlying Maatheide Member is slightly coarser with modal grain size around $250 \mu \mathrm{m}$ and better sorted. The continental nature of the Mol Formation is also indicated by its mineralogy. Compared to the clay mineralogy of the Pliocene marine deposits, the kaolinite content increases and smectite minerals disappear. The heavy minerals show a lower content of the marine derived mineral association and an increase of the alteration resistant minerals compared to marine deposits in the eastern Campine (Verhaegen, 2020, this volume, fig. 11). Gullentops \& Vandenberghe (1995a, fig. 7) note that the heavy mineral association predominantly consists of igneous tourmaline and parametamorphic species. The occasional presence of small kieseloolite pebbles (see Section 4.1.) links the Mol Formation to the Kieseloolite Formation occurring laterally of it in the Roer Valley Graben (see Fig. 5). The depositional setting of this Kieseloolite Formation consists of low-gradient rivers with extensive flood basins and peaty swamps (Westerhoff, 2009, p 127) in a wooded landscape enclosing oligotrophic mires (Vanhoorne in Vandenberghe et al., 2005) (see Section 6). The Maat Lignite in the Mol Formation, interpreted as having a late Pliocene (Reuver) age (see Section 4.1.) can be up to $4 \mathrm{~m}$ thick and is mixed with clay as expressed by higher gamma ray values in borehole logs (see Vandenberghe et al., 2020, this volume, fig. 5). This is analogous to the Brunssum clays and lignites of the Kieseloolite Formation which formed in swamps in a riverine landscape. Sequioa wood and pollen of pine and birch trees have been described in the Maat lignite (references in Gullentops \& Vandenberghe, 1995a) and are also described from the Brunssum clays and lignites in the Kieseloolite Formation in the Maaseik borehole (BGD 049W0220, DOV kb18d49w-B220; Vandenberghe et al., 2005; Fig. 1, Table 1).

A most remarkable property of the sand in the Mol Formation is the almost pure quartz composition that makes the sand a commercially valuable silica sand. This extreme compositional maturity of the large volume of sand of the Mol Formation, and also of the quartz-enriched sand in the Kieseloolite Formation, is hard to imagine without an already deeply weathered provenance area; the sediment was further enhanced by the leaching effect of acidic groundwater due to the presence of lignite (for a discussion on the alteration of the comparable lower to middle Miocene Opgrimbie silver sand, see van Loon, 2009). SEM surface textural analysis of the grains in the Mol Sand confirms the original subaqueous, high energetic environment, probably the river transport, followed by a post-depositional chemical alteration (Vos, 2018, p. 163). According to the cathodoluminescence colour spectra of the quartz grains, the ultimate source rock was plutonic with admixtures of low-grade metamorphic components similar to the Miocene Opgrimbie facies silica sand (Vos, 2018, p. 162). The systematic presence in the Mol Formation of small quantities of clay-sized glauconitic minerals points to the presence of glauconite bearing sand somewhere in the provenance area (Adriaens, 2015, p. 173).

\section{Merksplas Formation}

During the mapping of the Campine area, Gulinck (1962) described two sand units between the Pleistocene Campine clay, now part of the Pleistocene Weelde Formation, and the quartz sand of the continental Mol Formation or the marine Merksem Member of the Lillo Formation. The upper sand of the two sand units is the Brasschaat Member (now part of the Pleistocene Malle Formation) and the lower sand unit is the Pliocene Merksplas Formation. Only the Pliocene Merksplas Formation is discussed here. It consists of coarse-grained sand that had already been reported by Delvaux (1890) in a borehole four $\mathrm{km}$ north of Merksplas, and Gullentops \& Huyghebaert (1999, p. 198) considered it as a coastal barrier sand. The grain size is very coarse with a $300-400 \mu \mathrm{m}$ fraction (see e.g., borehole Huijbergen in Fig. 3) and with even some gravels and concentrations of reworked shells, contrasting with the finergrained $(150-250 \mu \mathrm{m})$ overlying Pleistocene Brasschaat Member. The sand of the Merksplas Formation is grey coloured, quartz-rich, and contains some glauconite, clay laminae and wood fragments and shell grit in its upper part. It is expressed on borehole logs by its high resistivity and low gamma ray signals (Fig. 3). Gulinck (1962) noted that in the southern part where it occurs, the coarse-grained sand of the Merksplas Formation could be absent beneath the Brasschaat Member. Recently the lithological description and the geographical extension of both units have been described and mapped (https://ncs.naturalsciences.be/paleogene-neogene/210-

merksplas-formation). The Merksplas Formation overlies the Poederlee Formation north of the Lichtaart-Kasterlee hill ridge and thickens northwards where it reaches $25 \mathrm{~m}$ near the Dutch border.

According to the borehole descriptions in the archives of the Geological Survey of Belgium, the term Merksplas Formation is used in areas where both the Merksplas Formation and the Brasschaat Member are present but no precise distinction can be made between the two stratigraphic units (P. Laga, pers. comm.). In regional studies (e.g., Buffel et al., 2001, 
figs 2, 3; Vandenberghe et al., 2000) the term Brasschaat Sand has been erroneously used instead of the Merksplas Sand, and in addition the Malle, Hemeldonk and Schorvoort units have been mapped in these regional studies as representing facies variation of the Merksplas Formation.

Vanhoorne (1962) analysed organic-rich samples of the sand intercalated between the Poederlee Formation and the Pleistocene Campine clay. Although the exact lithostratigraphic position of the samples is not known in detail, one of the samples (Kalmthout; BGD 006E0089, DOV kb7d6e-B115, 'pale grey very quartz-rich sand with lignite debris, $20 \mathrm{~m}$ below the clay'; Fig. 1, Table 1) almost certainly belongs to the Merksplas Formation. He interpreted the palynology as similar to the lignite in the Mol Formation and therefore also of Pliocene age. Although the interval $0-8 \mathrm{~m}$ in the Rees borehole (BGD 017E0399, DOV kb8d17e-B495) is considered as Pleistocene by Buffel et al. (2001), dinoflagellate cyst analysis by Al-Silwadi (2017) suggests a mid- to late Pliocene age for the interval 5-9 m depth.

\section{The Neeroeteren sand and the Kieseloolite Formation}

In the fault zone bordering the deeper subsidence area of the Roer Valley Graben in east Belgium occurs a particular coarsegrained facies, called 'the gravelly Neeroeteren quartz sand'. The unit was first reported by Gulinck (1962) and described in detail by Gullentops (1963, figs. 14, 15). The latter author described sedimentary structures with south-north orientated gullies and a poorly sorted grain-size distribution that he interpreted as a braided river fill deposited in a semi-arid climate. Both authors suggested cautiously that the unit represented a lateral facies of the Mol Formation. On an idealised section, Gullentops (1974) related the gravel in the Neeroeteren sand, and the sparse gravel in the Mol Formation (see Section 4) with the Hukkelberg Gravel at the base of the Poederlee Formation. However, in the legend of the 1:50 000 Geological Map 18-10 Maaseik-Beverbeek (Sels et al., 2001, Stop 4, p. 42, sand quarry Neeroeteren-Berg, quarry Opitter, BGD 064W0211, DOV kb26d64w-B217; Fig. 1, Table 1), this Neeroeteren sand is considered as the lower part of the Kieseloolite Formation, namely the Waubach sand and gravel. However, for the time being there is not much evidence to decide on a precise correlation of this sand with any particular unit within the Kieseloolite Formation.

Laga et al. (2001) defined the Kieseloolite Formation in the Belgian part of the Roer Valley Graben and considered it as a late Miocene and Pliocene deposit. For its subdivision into members these authors refer to the nomenclature developed in the more numerous sections in the Netherlands, except for the uppermost circa $45 \mathrm{~m}$ thick Jagersborg Member, part of which could be of Quaternary age. In the Dutch Roer Valley Graben, the different lithostratigraphic units identified are, from older to younger, the lower and upper Waubach Sand and Gravel, the Brunssum clay Member (with Pey Sand intercalated between the top and bottom clay), and an upper set of two laterally occurring units, the Shinveld Sand Member and the Reuver Clay Member (Wong et al., 2007, fig. 13). Note that Jagersborg in Belgium and Shinveld in the Netherlands refer to approximately the same sand unit in the Roer Valley Graben (see also Fig. 5).

The Kieseloolite Formation consists of the eroded, deeply weathered overburden of the Rhenish Massif, the Ardennes and exposed Belgian Cenozoic cover, transported by the Belgian rivers, the Meuse, and the Rhine. The sandy sediments are dominated by quartz and the heavy mineral association consists only of stable minerals. At the end of the Pliocene the composition turns to more unstable minerals in response to the enlargement of the Rhine river system and catchment area (Westerhoff, 2009). The name Kieseloolite Formation refers to the presence in the sand of small silicified oolite pebbles (kieseloolite) as also found in the Neeroeteren sand, the Mol Formation and the Hukkelberg Gravel. Some of these pebbles are even found as a lag deposit on the hill tops in a curve from Brugge to Kasterlee and are considered to mark the fossil shoreline (Gullentops \& Huyghebaert, 1999, p. 193). Similar oolitic pebble gravels also occur in the oldest river terrace along the Meuse between Namur and Huy and may therefore be coeval with the Kieseloolite Formation (e.g., Rixhon \& Demoulin, 2018).

The Kieseloolite Formation in the Belgian Roer Valley Graben is typically studied in the cored Maaseik borehole (049W0220; Vandenberghe et al., 2005 and revised in Louwye \& Vandenberghe, 2020, this volume). The formerly identified 'lower Waubach sand and gravel unit' is now considered to be equivalent to the upper part of the Tortonian Inden Formation in Germany. A $40 \mathrm{~m}$ thick deposit of permeable, coarse-grained sand forms the base of the Kieseloolite Formation, previously designated as the upper Waubach unit, and now called the Waubach Member. This member is assumed to be Messinian in age based on its palaeogeographical equivalence with the Hauptkies Schichten in the Lower Rhine Basin (Schäfer \& Utescher, 2014). The Kieseloolite Formation represents the fluviatile fill of the sinking Roer Valley Graben. At the time of the deposition of the Waubach Member the rivers were braided with a high sand load, while the clayey humic horizons in the section represent the floodplain. Two lignitic Brunssum clay levels (125-127 $\mathrm{m}$ and 88-76 m) occur, and in between both the permeable coarse-grained Pey Sand is present. Above the lignite and upper Brunssum clay fluviatile sand of the Shinveld Member or Jagersborg Member dominates again, with clay layers that are considered as the Reuver clay (Vandenberghe et al., 2005, fig.2). A finely laminated clay-sand facies in the Jagersborg Member is interpreted as a tidal influence in the river.

The study of the palynomorphs in the Maaseik borehole (Vanhoorne in Vandenberghe et al., 2005) distinguishes at 57$58 \mathrm{~m}$ a boundary between a lower palynozone A and an upper palynozone B (see Fig. 5). The upper part of the lower palynozone A, between $88-58 \mathrm{~m}$ depth, corresponding to the upper Brunssum clay and the lower part of the Jagersborg Sand, is an association that also occurs in the lignite of the Mol Formation (Vanhoorne 1973). Below, the Pey Sand and the lower Brunssum clay logically belong to the regional stage Brunssumian which is equivalent with the main part of the Zanclean. At the turn of the palynozone $\mathrm{A}$ to $\mathrm{B}$, the palynological association shows that the earlier densely forested landscape changes to a more open woodland landscape with extensive enclosed mires allowing light-demanding plants to grow. The palynomorphs further suggest that the continental Kieseloolite Formation in palynozone B, above 57-58 m, namely the upper part of the Jagersborg sand and Reuver clay deposits, probably rank into the regional Reuver stage which has a latest Zanclean and Piacenzian age. This Pliocene interpretation is preferred over a Pretiglian earliest Quaternary age because thermophilous trees and Tertiary type palynomorphs continuously occur while the Ericales are considered to originate from oligotrophic mires in the forest.

Taking into account the difference between the Pliocene marine and continental deposits in the west, the boundary between the palynozones A and B at $58 \mathrm{~m}$ depth in the Maaseik borehole is assumed to correspond reasonably well to the 'Merxemien' (Merksem and Kruisschans Members of the Lillo Formation) and 'Scaldisien' (the Oorderen Member) boundary sensu de Heinzelin (1955). 


\section{The Pliocene palaeogeographical evolution in northern Belgium}

\subsection{Eastern Campine area}

By the end of the Tortonian the marine glauconitic Kasterlee Formation in the Antwerp Campine was replaced eastwards by a more coastal-plain facies, namely the clayey Kasterlee unit and the overlying 'lower Mol' or 'Kasterlee-sensu-Gulinck' quartz sand, while even further eastwards in the Roer Valley Graben the fluvial and lacustrine to lagoonal Inden Formation was deposited. This east to west facies evolution, from fluvial to coastal and marine facies continues during the Pliocene (Fig. 5). During the Zanclean, the fluvial and swamp deposits in the sinking Roer Valley Graben existed alongside a mainly emerged landmass outside the graben, where only in the very western part of the Antwerp Campine experienced brief and limited transgressive phases, which lead to the deposition of the Kattendijk Formation, the Broechem layer and the shelly Luchtbal Member. The Maat lignite overlies the Donk Member in the Mol Formation. As the palynology shows similar associations in this Maat lignite and in the upper part of palynozone A (Vanhoorne, 1973), the quartz-rich fluvial and floodplain sand had started somewhat earlier to spill over the Roer Valley Graben border covering the Campine graben shoulder and forming the Donk Sand. A further stepwise westwards progression of the Mol Sand over the Campine area is suggested in Figure 5 and probably the Rauw Fault scarp has been a physical limit for one of these prograding steps.

During the latest Zanclean and during the Piacenzian, the fluvial Jagersborg/Shinveld Sand and lacustrine to lagoonal Reuver clay were deposited in the sinking Roer Valley Graben while the Maatheide Member and Russendorp lignite of the Mol Formation were deposited over the eastern Campine (Vandenberghe et al., 2020, fig 5, this volume). In the Kasterlee -Retie area the Mol Formation transitions laterally into the marine Poederlee Formation. The relationship between these units is not only geometrical but further confirmed by the dispersed occurrence in the Mol Formation of silicified oolites and small discoidal quartz pebbles which are typical for the Hukkelberg Gravel at the base of the Poederlee Formation. Furthermore, there are also lumps of white Mol-type sand in the base of the Poederlee Formation (Gulinck, 1960; see Vandenberghe et al., 2020, this volume). The Poederlee Formation heavy mineral association and its lower glauconite content also indicate that it is more influenced by a continental provenance than the more western members of the Lillo Formation; this is confirmed by the fact that terrestrial palynomorphs in the Poederlee Formation largely outnumber the marine palynomorphs. The fossil content and geometric position of the Poederlee Formation (Deckers \& Louwye, 2020, this volume) suggest a time equivalence with the more marine uppermost Oorderen, Kruisschans and lowermost Merksem Members (see Section 3.3.) The dinoflagellate cysts from the Poederlee Formation are indicative of deposition during the latest Zanclean to the middle Piacenzian (see Section 3.2.).

The Poederlee Formation in the subsurface of the Antwerp Campine is overlain by a series of quartz-sand facies that contain wood fragments and become finer grained towards the east where some glauconite grains also appear. From east to west, these Rees, Schorvoort, Hemeldonk and Malle facies represent the transition from the upper part of the Mol Formation to the Merksplas Formation. The palynological data show that the lignites in the Mol Formation and the humic samples of the Merksplas Formation are comparable and are coeval with the marine Merksem Member of the Lillo Formation. In summary, during the late Zanclean and the Piacenzian a gradual westward expansion of the fluviatile to estuarine Mol and Merksplas Formations occurs thereby gradually shifting the shoreline and the marine deposits.

\subsection{Western Campine area}

The westward expansion of the fluviatile facies discussed above arrives in the western Campine by the very end of the Pliocene and forms the Merksplas Formation. At that moment there is probably still marine deposition in the Antwerp Harbour area forming the top of the Merksem Member and the Zandvliet Member.

Prior to this, already since the beginning of the Pliocene marine deposits with a limited geographical extent formed in this western area of the Antwerp Campine area. In the early Zanclean, the marine Kattendijk Formation formed across the wider area around present day Antwerp, then during the late Zanclean, the thin Broechem layer and the shelly Luchtbal Member developed in the Antwerp harbour and Campine areas. Between these depositional phases the sea retreated from the area leaving hiatuses; the same happened between the Luchtbal Member and the Oorderen Member (Fig. 5). During the Piacenzian a continuous marine succession formed starting at the base with deposition of the sand of the Oorderen Member, followed by the clayey Oorderen sand, the Kruisschans Member, the Merksem Member and finally at the top Zandvliet Member. This continuous marine Piacenzian of about $30 \mathrm{~m}$ thickness was deposited during a general fall in global sea level, suggesting that the accommodation space needed for the sediments to accumulate was created by subsidence in the Antwerp Campine.

Dinoflagellate cysts indicate a nearshore depositional environment for the Oorderen and Kruisschans Members (Louwye et al., 2004; De Schepper et al., 2009), especially at the base of the Oorderen Member and the top of the Kruisschans Member. The dinocyst Invertocysta lacrymosa, considered as an open-marine species, suddenly disappears at the upper boundary of the Oorderen Member pointing to a shallower depositional environment of the overlying marine members. The latter authors considered this environmental evolution as a tentative argument to regard the Oorderen Member and Kruisschans Member as deposited during one transgressive depositional cycle, with the gravel bed at the base of the Oorderen Member representing a transgressive surface during the warm middle Pliocene. Goolaerts (2000) interprets the section of the Lillo Formation in the Verrebroek Dock as a single shallowing upwards cycle, from offshore at the base to foreshore at the top, without clear breaks but with gradual transitions between the different lithological members.

De Heinzelin (1955) and Tavernier \& de Heinzelin (1962) suggest that the Kruisschans Member was deposited as part of a new transgression after regression in the top of the 'Scaldisien' (now the top of the Oorderen Member). Vandenberghe et al. $(2000,2004)$ have also argued for the presence of two cycles in the Oorderen to Zandvliet succession of units, with arguments referring e.g., to the presence of the Amerika Dock gravel that is now apparently more widespread than previously thought (see Section 2) and the existence at Grobbendonk of a tidal flat clay coeval to the Kruisschans Member according to dinoflagellate cyst biostratigraphy (Vandenberghe et al., 2000). However, De Schepper et al. (2009) proposed, based on dinoflagellate cyst analysis, a correlation with the younger Oorderen Member (see above). After an initial transgression, the Merksem Member above indicates shallowing again.

De Schepper et al. (2009) equated the transgressive gravel at the base of the Kattendijk Formation with the sequence boundary correlated to Me2 at 5.5 Ma (Hardenbol et al., 1998). This sequence boundary is related to the glacial stage TG20 at 

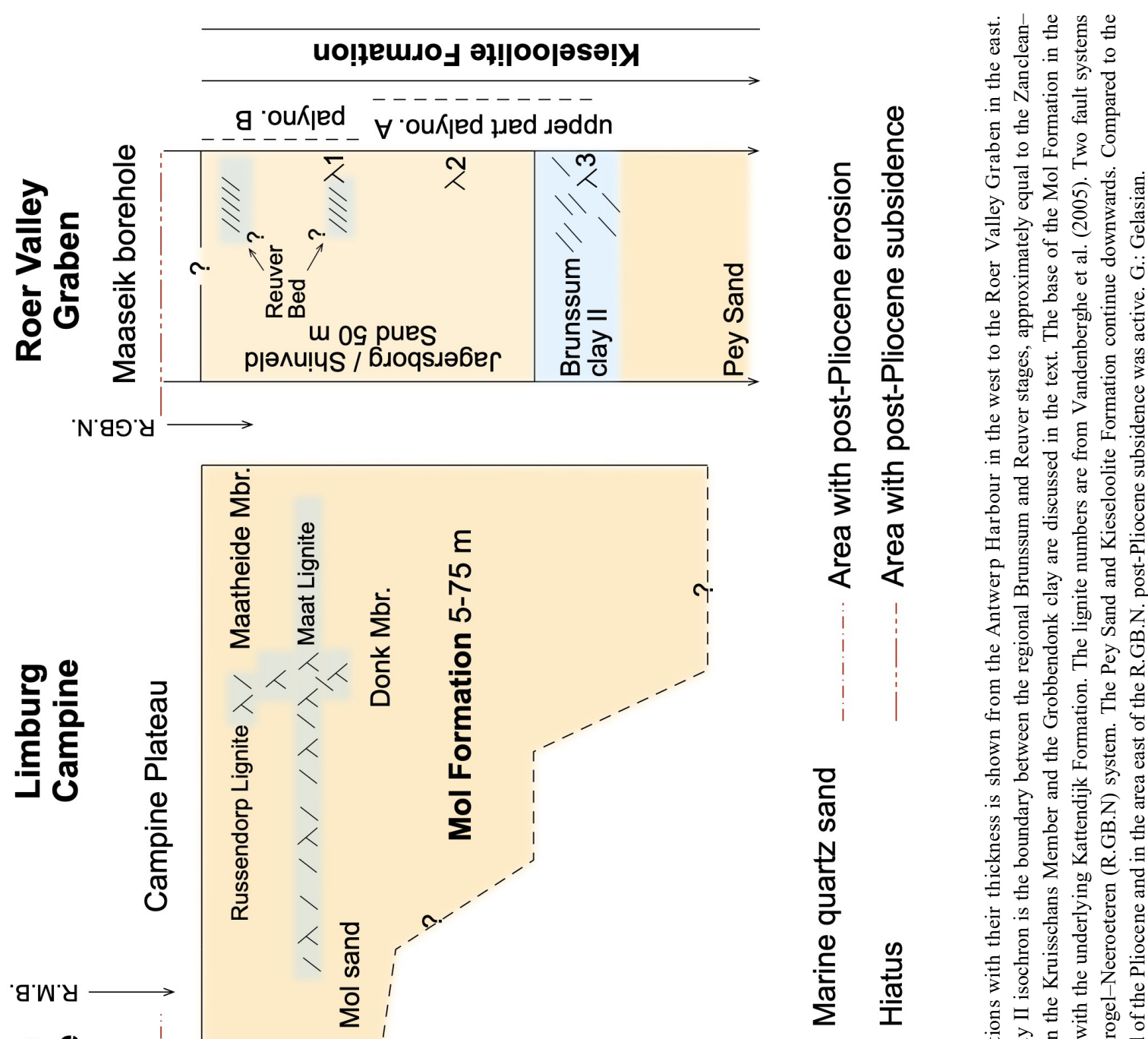

은

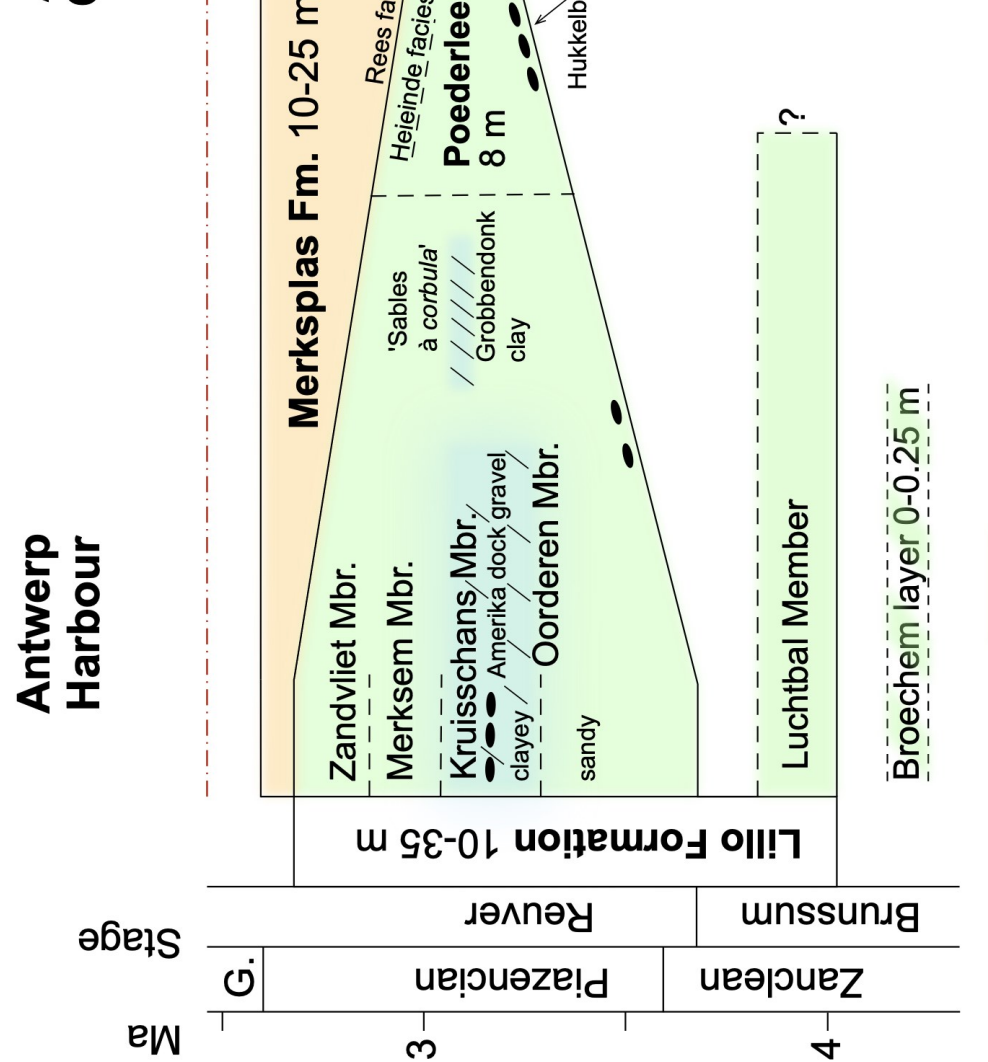

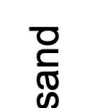

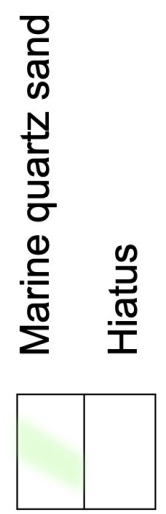

맊

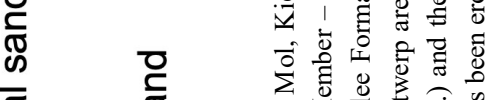

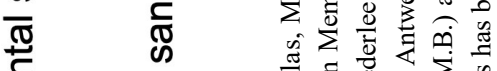

ब $\quad 0 \quad$ 至

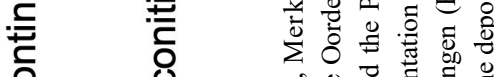

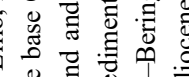

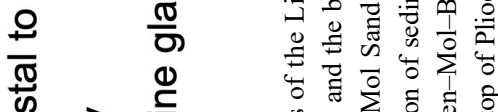

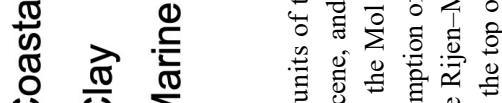

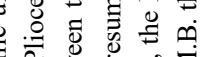
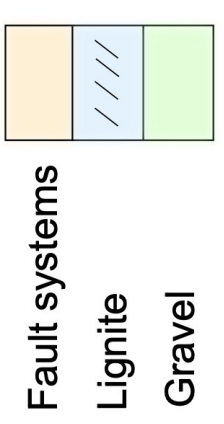

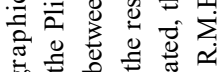

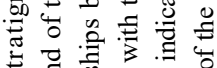

फे

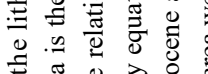

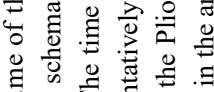

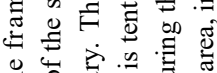

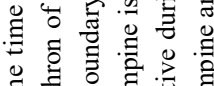

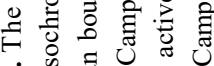
is. .

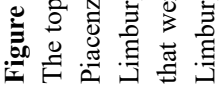


5.75 Ma (Hoddel et al., 2001; see Louwye et al., 2007 for discussion) and corresponds to a sea-level lowering of circa 50 $\mathrm{m}$. The superjacent Luchtbal Member of the Lillo Formation, a lag deposit, may correspond to the sequence between boundaries $\mathrm{Za} 2$ at $4.04 \mathrm{Ma}$ and Pia1 at 3.21 Ma (De Schepper et al., 2009). The $\mathrm{Za} 2$ sequence boundary is also probably related to a sea-level fall related to glacials MIS Gi20 and Gi22 (Lisiecki \& Raymo, 2005). In the younger Piacenzian Oorderen to Zandvliet succession, stratigraphic resolution is not high enough to compare sedimentary evolution with global sea-level sequences, and furthermore it is probably that local factors steered the relative sea-level variations in the area.

The marine Poederlee Formation occurs geometrically between the marine Lillo Formation in the west and the continental sediments of the Mol Formation in the east. This intermediate position is also evidenced by its mineralogy and palynomorph content (see Section 3.2.). Precise correlation with the Lillo Formation to the west remains debatable and arguments have already been presented (see Section 3.3.); geometrically the Oorderen Member wedges out laterally from the base of the Poederlee Formation whilst the top part of the Poederlee Formation is correlatable to the transition zone of the top of the Kruisschans and base of the Merksem Members. The fine sand with Corbula shells in the Antwerp Campine (Gulinck, 1962) is considered as the lateral equivalent of the Merksem Sand as defined in the Antwerp Harbour area in line with the description of the 'étage Poederlien' as 'Sand with Corbula gibba' in the explanatory text of the original geological maps (Légende de la Carte géologique, 1909), and as was followed by Tavernier (1954, p. 546) and Tavernier \& de Heinzelin (1962). The term 'Poederlien' was actually introduced by Vincent (1889) to replace the name 'Sables à Corbula gibba de Merxem' (quoted in Laga, 1972, p. 228).

The close relationship of the Poederlee Formation and the Mol Formation to the east is shown by the inclusion of clasts of white Mol Sand in the Poederlee Formation (see Section 7.1.). The characteristic small discoidal quartz pebbles of the Hukkelberg Gravel at the base of the Poederlee Member have also been reported at the base of the Lillo Formation in the Schilde borehole (029W0372).

\section{Conclusions}

The considerable amount of dispersed data in the literature relating to the Pliocene of northern Belgium has been integrated into a coherent synthesis of the Pliocene of North Belgium and the reconstruction of the depositional history. The main historical descriptions and definitions of lithostratigraphic units have been placed in the perspective of present stratigraphic understanding. This synthetic view makes use of field observations, mineralogy and palynology in clarifying the position of the Poederlee Formation as intermediate between the fully marine and the continental deposits. Furthermore, the gradual Pliocene evolution of the palaeogeography is shown, with the shifting positions of land, rivers and swamps, and marine sand. This scheme forms the starting point for developing strategies for further progress by well-planned combined sedimentological, mineralogical and palaeontological investigations with a particular combination of terrestrial and marine palynology, and will thus constitute the basis for a thorough review of the nomenclature and hierarchy of the Pliocene stratigraphic units discussed here.

\section{Acknowledgements}

Marleen De Ceuckelaire (Geological Survey of Belgium, Brussels) is thanked for the retrieval of archive documents. The constructive reviews by Koen Beerten, Ian Harding and Johan Matthijs are kindly acknowledged.

\section{References}

Adriaens, R., 2015. Neogene and Quaternary clay minerals in the southern North Sea. Unpublished Ph.D. Thesis, KU Leuven, Leuven, 272 p. https:/limo.libis.be/primo-explore/fulldisplay? docid=LIRIAS1930587\&context=L\&vid=Lirias\&search_scope=Lirias\&ta $\mathrm{b}=$ default tab\&lang=en US\&fromSitemap $=1$, accessed 10/12/2020.

Al-Silwadi, S., 2017. Dinoflagellate cyst stratigraphy and paleoecology of the Upper Miocene and Pliocene, Rees Borehole, Northern Belgium. Unpublished MSc. Thesis Earth Science, Brock University, Ontario, Canada, 128 p.

Braga, J.C. \& Martín, J.M., 1996. Geometries of reef advance in response to relative sea-level changes in a Messinian (uppermost Miocene) fringing reef (Cariatiz reef, Sorbas Basin, SE Spain) Sedimentary Geology, 107, 61-81. https://doi.org/10.1016/S00370738(96)00019-X

Buffel, P., Vandenberghe, N., Goolaerts, S. \& Laga, P., 2001. The Pliocene in four boreholes in the Turnhout area (North-Belgium): the relation with the Lillo and Mol Formations. Aardkundige Mededelingen, 11, 1-9.

Cogels, P., 1874. Observations géologiques et paléontologiques sur les différents dépôts rencontrés à Anvers lors du creusement des nouveaux bassins. Annales de la Société malacologique de la Belgique, Mémoires, 9, 7-32.

Cogels, P. \& Van Ertborn, O., 1881. Coup d'œil rétrospectif sur nos travaux et leurs résultats. Le fort de Lierre. La roche de Poederlé. In Mélanges géologiques, Vol. 3. J.H. Van der Wielen, Anvers, 61-88.

Dearing Crampton-Flood, E., Peterse, F., Munsterman, D. \& Sinninghe Damsté, J.S., 2018. Using tetraether lipids archived in North Sea Basin sediments to extract North Western European Pliocene continental air temperatures. Earth and Planetary Science Letters, 490, 193-205. https://doi.org/10.1016/j.epsl.2018.03.030

Dearing Crampton-Flood, E., Noorbergen, L.J., Smits, D., Boschman, R.C., Donders, T.H., Munsterman, D.K., ten Veen, J., Peterse, F., Lourens, L. \& Sinninghe Damsté, J.S., 2020. A new age model for the Pliocene of the southern North Sea basin: a multi-proxy climate reconstruction. Climate of the Past, 16/2, 523-541. https:// doi.org/10.5194/cp-16-523-2020

Deckers, J. \& Louwye, S., 2020. The architecture of the Kattendijk Formation and the implications on the early Pliocene depositional evolution of the southern margin of the North Sea Basin. Geologica Belgica, 23/3-4, this volume. https://doi.org/10.20341/gb.2020.017

Deckers, J., De Koninck, R., Bos, S., Broothaers, M., Dirix, K. Hambsch, L., Lagrou, D., Lanckacker, T., Matthijs, J., Rombaut, B., Van Baelen, K. \& Van Haren, T., 2019. Geologisch (G3Dv3) en hydrogeologisch (H3D) 3D-lagenmodel van Vlaanderen. Studie uitgevoerd in opdracht van het Vlaams Planbureau voor Omgeving, departement Omgeving en de Vlaamse Milieumaatschappij. VITO, Mol, VITO-rapport 2018/RMA/R/1569, 286 p. https://archiefalgemeen.omgeving.vlaanderen.be/xmlui/handle/acd/251494, accessed 10/12/2020.

Deckers, J., Louwye, S. \& Goolaerts, S., 2020. The internal division of the Pliocene Lillo Formation: correlation between Cone Penetration Tests and lithostratigraphic type sections. Geologica Belgica, 23/34, this volume. https://doi.org/10.20341/gb.2020.027

de Heinzelin, J. 1950. Stratigraphie pliocène et quaternaire observée au Kruisschans. II. Conclusions. Bulletin de 1'Institut royal des Sciences naturelles de Belgique, 41/26, 1-20.

de Heinzelin de Braucourt, J., 1952. Note sur les coupes de l'écluse Baudouin à Anvers. Bulletin de la Société belge de Géologie, de Paléontologie et d'Hydrologie, 61, 106-108.

de Heinzelin, J., 1955. Considérations nouvelles sur le Néogène de l'Ouest de l'Europe. Bulletin de la Société belge de Géologie, de Paléontologie et d'Hydrologie, 64/3, 463-476.

de Jong, J., 1988. Climatic variability during the past three million years, as indicated by vegetational evolution in northwest Europe and with emphasis on data from The Netherlands. Philosophica Transactions of the Royal Society of London B, 318, 603-617. https://doi.org/10.1098/rstb.1988.0025

Delheid, E., 1895. Contributions paléontologiques à l'étude de l'étage Pliocène, à Anvers. Bulletin de la Société belge de Géologie, de Paléontologie et d'Hydrologie, 9, 57-62.

Delvaux, E., 1890. Etude stratigraphique et paléontologique du sous-sol de la Campine. Annales de la Société géologique de Belgique, 18, 106-156.

De Meuter, F. \& Laga, P. 1976. Lithostratigraphy and biostratigraphy based on benthonic Foraminifera of the Neogene deposits of northern Belgium. Bulletin van de Belgische Vereniging voor Geologie, 85/4, 133-152.

De Schepper, S. \& Head, M.J., 2008. Age calibration of dinoflagellate cyst and acritarch events in the Pliocene-Pleistocene of the eastern North Atlantic (DSDP Hole 610A). Stratigraphy, 5/2, 137-161. 
De Schepper, S. \& Head, M.J. 2009. Pliocene and Pleistocene dinoflagellate cyst and acritarch zonation of DSDP Hole 610A, eastern North Atlantic. Palynology, 33/1, 179-218. https:// doi.org/10.2113/gspalynol.33.1.179

De Schepper, S., Head, M. J. \& Louwye, S., 2009. Pliocene dinoflagellate cyst stratigraphy, palaeoecology and sequence stratigraphy of the Tunnel-Canal Dock, Belgium. Geological Magazine, 146, 92-112. https://doi.org/10.1017/ S0016756808005438

De Schepper, S., Gibbard, P.L., Salzmann, U. \& Ehlers, J., 2014. A global synthesis of the marine and terrestrial evidence for glaciation during the Pliocene Epoch. Earth-Science Reviews, 135, 83-102. https://doi.org/10.1016/j.earscirev.2014.04.003

de Verteuil, L. \& Norris, G., 1996. Miocene dinoflagellate stratigraphy and systematics of Maryland and Virginia. Micropaleontology, 42, Supplement, 1-172. https://doi.org/10.2307/1485926

Doppert, J. W. C., Laga, P. \& De Meuter, F., 1979. Correlation of the biostratigraphy of marine Neogene deposits, based on benthonic foraminifera, established in Belgium and The Netherlands. Mededelingen Rijks Geologische Dienst, 31, 1-8.

Dumont, A., 1850. Rapport sur la carte géologique du Royaume. Bulletins de l'Académie royale des Sciences, des Lettres et des Beaux-Arts de Belgique, 16/2 (1849), 351-373.

Edelman, C.H. \& Doeglas, D.J., 1933. Bijdrage tot de petrologie van het Nederlandsche Tertiair. Verhandelingen van het Geologischmijnbouwkundig genootschap voor Nederland en koloniën, Geologische serie, 10, 1-38.

Everaert, S., De Schutter, P., Mariën, G., Cleemput, G., Van Boeckel, J., Rondelez, D., Bor, T., 2019. Een vroeg-miocene fauna uit het Zand van Kiel (Formatie van Berchem) bij Post $\mathrm{X}$ in Berchem (Antwerpen). Afzettingen WTKG Werkgroep Tertiair en Kwartair Geologie, 40/4, 83-100.

Funnell, B.M., 1996. Plio-Pleistocene palaeogeography of the southern North Sea basin (3.75-0.60 Ma). Quaternary Science Reviews, 15, 391- 405. https://doi.org/10.1016/0277-3791(96)00022-4

Gaemers, P.A.M., 1975. Enkele paleo-ecologische opmerkingen over de pliocene afzettingen in de tunnelput nabij Kallo, België, provincie Oost-Vlaanderen. Mededelingen van de Werkgroep voor Tertiaire en Kwartaire Geologie, 12/1, 25-37.

Gaemers, P.A.M., 1988. The regional distribution of otolith assemblages; correlation of the interregional zonation with the regional lithostratigraphic formations. In Vinken, R. (ed.), The Northwest European Tertiary Basin. Geologisches Jahrbuch, Reihe A, 100, 379-389.

Geets, S., 1962. Stratigrafische positie van het Poederliaan in de Antwerpse Kempen. Natuurwetenschappelijk Tijdschrift, 44, 143-152.

Geets, S. \& De Breuck, W., 1991. De zware-mineraleninhoud van Belgische mesozoïsche en cenozoïsche afzettingen. G. Neogeen. Natuurwetenschappelijk Tijdschrift, 73, 3-37.

Gibbard, P.L. \& Lewin, J., 2016. Filling the North Sea Basin: Cenozoic sediment sources and river styles. Geologica Belgica, 19/3-4, 201217. https://doi.org/10.20341/gb.2015.017

Goolaerts, S., 2000. Sedimentologische, stratigrafische en paleoecologische studie van de Pliocene en Quartaire afzettingen aangetroffen in fase 2 van het Verrebroekdok, provincie OostVlaanderen. Unpublished Master Thesis, KU Leuven, Leuven, 133 p.

Gulinck, M., 1960. Un gisement de kiezeloolithes à Lichtaart (Campine). Comparaison avec les cailloutis à kiezeloolithes des collines flamandes. Bulletin Société belge de Géologie, de Paléontologie et d'Hydrologie, 69, 191-204.

Gulinck, M., 1962. Essai d'une carte géologique de la Campine. Etat de nos connaissances sur la nature des terrains néogènes recoupés par sondages. Mémoires de la Société belge de Géologie, de Paléontologie et d'Hydrologie, série in- $8^{\circ}, 6,30-39$.

Gulinck, M. \& Laga, P., 1975. Boring SCK te Mol 31W-237. Geologische beschrijving door de Belgische Geologische Dienst. Archives of the Geological Survey of Belgium. http:// gisel.naturalsciences.be/data/text/031W/031W0237.txt, accessed 15/03/2020.

Gulinck, M., Geets, S. \& Van Voorthuyzen, J.H., 1963. Note sur les sondages du centre nucléaire à Mol. Bulletin de la Société belge de Géologie, de Paléontologie et d'Hydrologie, 72, 283-394.

Gullentops, F., 1963. Etude de divers faciès quaternaires et tertiaires dans le Nord et l'Est de la Belgique. Excursion O-P. 6e Congrès International de Sédimentologie, Belgique et Pays-Bas, $20 \mathrm{p}$.

Gullentops, F., 1974. Field trip notes 21-22 June 1975. Société belge de Géologie \& Société géologique de Belgique.

Gullentops, F. \& Huyghebaert, L., 1999. A profile through the Pliocene of the Northern Kempen, Belgium. Aardkundige Mededelingen, 9, 191-202.

Gullentops, F. \& Vandenberghe, N., 1995a. Toelichtingen bij de geologische kaart van België, Vlaams Gewest: kaartblad 17, Mol [1/50 000]. Belgische Geologische Dienst en Ministerie van de
Vlaamse Gemeenschap, Afdeling Natuurlijke Rijkdommen en Energie, Brussel, $65 \mathrm{p}$

Gullentops, F. \& Vandenberghe, N., 1995b. Geologische kaart van België, Vlaams Gewest: Mol, kaartblad 17. 1/50 000. Belgische Geologische Dienst en Afdeling Natuurlijke Rijkdommen en Energie, Brussel.

Gullentops, F. \& Wouters, L., 1996. Delfstoffen in Vlaanderen. Ministerie van de Vlaamse Gemeenschap, Department Economie, Werkgelegenheid, Binnenlandse Aangelegenheden en Landbouw, Afdeling Natuurlijke Rijkdommen en Energie, Brussel, 198 p.

Hacquaert, N., 1960. Palynologisch onderzoek van de cenozoische mariene zanden (Scaldisien en Merxemien) van het Hansadok te Antwerpen. Natuurwetenschappelijk Tijdschrift, 42, 65-112.

Hacquaert, N., 1962. Etude palynologique des sables marins scaldisiens et merxemiens du Hansadok à Anvers. Mémoires de la Société belge de Géologie, de Paléontologie et d'Hydrologie, série in- $8^{\circ}, 6$, $96-100$.

Halet, F., 1935. Les formations néogènes au Nord et à l'Est de la ville d'Anvers. Bulletin de la Société belge de Géologie, de Paléontologie et d'Hydrologie, 45, 141-153.

Hardenbol J., Thierry J., Farley M.B., Jacquin T., de Graciansky P.-C. \& Vail P.R., 1998. Mesozoic and Cenozoic sequence chronostratigraphic framework of European Basins. In de Graciansky, P.-C., Hardenbol, J., Jacquin, T. \& Vail, P.R. (eds), Mesozoic and Cenozoic Sequence Stratigraphy of European Basins. SEPM (Society for Sedimentary Geology), Tulsa (OK), SEPM Special publication, 60, 3-14. https://doi.org/10.2110/pec.98.02.0003

Hinsch, W., 1988. Benthic molluscs (Pelecypods, Gastropods), the description of the interregional zonation (BM zones) and its correlation with the regional lithostratigraphy. In Vinken, R. (ed.), The Northwest European Tertiary Basin. Geologisches Jahrbuch, Reihe A, 100, 344-356.

Hodell, D.A., Curtis, J.H., Sierro, F.J. \& Raymo, M.E., 2001 Correlation of late Miocene to early Pliocene sequences between the Mediterranean and North Atlantic. Paleoceanography, 16, 164178. https://doi.org/10.1029/1999PA000487

Janssen, A. \& King, C., 1988. The description of a tentative interregional pteropod (planktonic gastropods) zonation and its correlation with the regional lithostratigraphy. In Vinken, R. (ed.), The Northwest European Tertiary Basin. Geologisches Jahrbuch, Reihe A, 100, 357-366.

Laga, P., 1972. Stratigrafie van de mariene Plio-Pleistocene afzettingen uit de omgeving van Antwerpen met een bijzondere studie van de foraminiferen. Unpublished Ph.D. thesis, KU Leuven, Leuven, 252 p.

Laga, P., 1973. The Neogene deposits of Belgium. Guidebook for the Field Meeting of the Geologists' Association London, 31 March-3 April, 1973. Geological Survey of Belgium, Brussels, $31 \mathrm{p}$

Laga, 1983. Borehole description Schilde 029W0372. Archives of the Geological Survey of Belgium. http://gisel.naturalsciences.be/data/ text/029W/029W0372, accessed 17/08/2020.

Laga, P., Louwye, S. \& Geets, S., 2001. Paleogene and Neogene lithostratigraphic units (Belgium). Geologica Belgica, 4/1-2, 135152. https://doi.org/10.20341/gb.2014.050

Laga, P., De Schepper, S., Louwye, S \& Herman, J., 2015. Het Plioceen. In Borremans, M. (ed.), Geologie van Vlaanderen. Academia Press, Gent, 165-175.

Légende de la Carte géologique de la Belgique à l'échelle du 40.000e, 1909. Ministère de 1'Industrie et du Travail, Direction Générale des Mines, Commission géologique de Belgique, Bruxelles, $26 \mathrm{p}$.

Leriche, M., 1912. Le Néogène des environs d'Anvers. Bulletin de la Société géologique de France, $4^{\mathrm{e}}$ série, 12, 725-727.

Leriche, M., 1913. Sur l'âge des sables de Moll. Bulletin de la Société belge de Géologie, de Paléontologie et d'Hydrologie, 27, 92-96.

Leriche, M., 1927. Les couches de base du Scaldisien au nord d'Anvers. Bulletin de la Société belge de Géologie, de Paléontologie et d'Hydrologie, 36, 36-52.

Lisiecki, L.E. \& Raymo, M.E., 2005. A Pliocene-Pleistocene stack of 57 globally distributed benthic $\delta^{18} \mathrm{O}$ records. Paleoceanography and Paleoclimatology, 20, PA1003, 1-17. https:// doi.org/10.1029/2004PA001071

Louwye, S. \& De Schepper, S., 2010. The Miocene-Pliocene hiatus in the southern North Sea Basin (northern Belgium) revealed by dinoflagellate cysts. Geological Magazine, 147/5, 760-776. https:// doi.org/10.1017/S0016756810000191

Louwye, S. \& Laga, P., 1998. Dinoflagellate cysts of the shallow marine Neogene succession in the Kalmthout well, northern Belgium. Bulletin of the Geological Survey of Denmark, 45, 73-86.

Louwye, S. \& Vandenberghe, N., 2020. A reappraisal of the stratigraphy of the upper Miocene unit $\mathrm{X}$ in the Maaseik well, eastern Campine area (northern Belgium). Geologica Belgica, 23/3-4, this volume. https://doi.org/10.20341/gb.2020.013

Louwye, S., Head, M. \& De Schepper, S., 2004. Dinoflagellate cyst stratigraphy and palaeoecology of the Pliocene in northern 
Belgium, southern North Sea Basin. Geological Magazine, 141/3, 353-378. https://doi.org/10.1017/S0016756804009136

Louwye, S., De Schepper, S., Laga, P. \& Vandenberghe, N., 2007. The Upper Miocene of the southern North Sea Basin (northern Belgium): a palaeoenvironmental and stratigraphical reconstruction using dinoflagellate cysts. Geological Magazine, 144/1, 33-52. https://doi.org/10.1017/S0016756806002627

Marquet, R., 1993. The molluscan fauna of the Kruisschans Member (Lillo Formation, Late Pliocene) in the Antwerp area (Belgium). Contributions to Tertiary and Quaternary Geology, 30/3-4, 83-103.

Marquet, R., 1998. De Pliocene gastropodenfauna van Kallo (OostVlaanderen, België). Belgische Vereniging voor Paleontologie, 17, 246 p.

Marquet, R., 2002. The Neogene Amphineura and Bivalvia (Protobranchia and Pteriomorphia) from Kallo and Doel (OostVlaanderen, Belgium). Palaeontos, 2, $99 \mathrm{p}$.

Marquet, R., 2004. Ecology and evolution of Pliocene bivalves from the Antwerp Basin. Bulletin de l'Institut royal des Sciences naturelles de Belgique, Sciences de la Terre, 74, 205-212.

Miller, K.G., Kominz, M.A., Browning, J.V., Wright, J.D., Mountain, G.S., Katz, M.E., Sugarman, P.J., Cramer, B.J., Christie-Blick, N \& Pekar, S.F., 2005. The Phanerozoic record of global sea-level change. Science, 310, 1293-1298. https://doi.org/10.1126/science.1116412

Mourlon, M., 1880. Géologie de la Belgique, t. 1., Terrains MioPliocènes. Hayez, Bruxelles, 261-282.

Mourlon, M., 1882. Mémoires sur les Terrains Crétacé et Tertiaires préparés par feu André Dumont, t. IV. Hayez, Bruxelles, 702 p.

Mourlon, M., 1898. Les dépôts tertiaires de la Campine limbourgeoise. Bulletin de la Société belge de Géologie, de Paléontologie et d'Hydrologie, 12, 45-58.

Mourlon, M., 1907. Sur la nouvelle interprétation du Sable de Moll en Campine. Bulletin de la Société belge de Géologie, de Paléontologie et d'Hydrologie, 21, 578-587.

Olivero, E.B. \& López Cabrera, M.I., 2010 Tasselia ordamensis: A biogenic structure of probable deposit-feeding and gardening maldanid polychaetes. Palaeogeography, Palaeoclimatology, Palaeoecology, 292, 336-348. https://doi.org/10.1016/j.palaeo.2010.04.018

Overeem, I., Weltje, G.J., Bishop-Kay, C. \& Krooneberg, S.B., 2001 The Late Cenozoic Eridanos delta system in the Southern North Sea Basin: a climate signal in sediment supply? Basin Research, 13, 293 -312. https://doi.org/10.1046/j.1365-2117.2001.00151.x

Powell, A.J., 1992. Dinoflagellate cysts of the Tertiary System. In Powel, A.J. (ed.), A stratigraphic index of dinoflagellate cysts. Chapman \& Hall, London, 155-251.

Rixhon, G. \& Demoulin, A., 2018. The picturesque Ardennian Valleys: Plio-Quaternary incision of the drainage system in the uplifting Ardenne. In Demoulin, A. (ed.), Landscapes and Landforms of Belgium and Luxembourg. Springer, Cham, World Geomorphological Landscapes, 159-175. https://doi.org/10.1007/978-3-319-58239-9_10

Schäfer, A. \& Utescher, T., 2014. Origin, sediment fill, and sequence stratigraphy of the Cenozoic Lower Rhine Basin (Germany) interpreted from well logs. Zeitschrift der Deutschen Gesellschaft für Geowissenschaften, 165/2, 287-314. https://doi.org/10.1127/1860-1804/2014/0062

Schiltz, M., Vandenberghe, N. \& Gullentops, F., 1993. Geologische kaart van België, Vlaams Gewest: Lier, kaartblad 16. 1/50 000 Belgische Geologische Dienst en Bestuur Natuurlijke Rijkdommen en Energie, Brussel.

Sels, O., Claes, S. \& Gullentops, F., 2001. Toelichtingen bij de geologische kaart van België, Vlaams Gewest: kaartblad 18-10, Maaseik - Beverbeek [1/50 000]. Belgische Geologische Dienst en Ministerie van de Vlaamse Gemeenschap, Afdeling Natuurlijke Rijkdommen en Energie, Brussel, 50 p.

Spiegler, D., 2001. Bolboforma biostratigraphy in the Neogene glauconitic sands of Belgium. Aardkundige Mededelingen, 11, 61-68.

Tavernier, R., 1954. Le Néogène. In Fourmarier, P. (ed.), Prodrome d'une description géologique de la Belgique, Volume hommage à Paul Fourmarier. Société géologique de Belgique, Liège, 533-554.

Tavernier, R. \& de Heinzelin, J., 1962. Introduction au Néogène de la Belgique. Mémoires de la Société belge de Géologie, de Paléontologie et d'Hydrologie, série in- $8^{\circ}, 6,7-28$.

Utescher, T., Ashraf, A.R., Dreist, A., Dybkjær, K., Mosbrugger, V., Pross, J. \& Wilde, V., 2012. Variability of Neogene continental climates in Northwest Europe - A detailed study based on microfloras. Turkish Journal of Earth Sciences, 21, 289-314. https://doi.10.3906/yer-1005-3

Vandenberghe, N. \& Hardenbol, J., 1998. Introduction to the Neogene. In de Graciansky, P.-C., Hardenbol, J., Jacquin, T. \& Vail P.R. (eds), Mesozoic and Cenozoic Sequence Stratigraphy of European Basins. SEPM (Society for Sedimentary Geology), Tulsa (OK), SEPM Special Publication, 60, 83-85. https://doi.org/10.2110/pec.98.02.0083

Vandenberghe, N., Herman, J., Laga, P., Louwye, S., De Schepper, S., Vandenberghe, J., Bohncke, S.J.P. \& Konert, M., 2000. The stratigraphic position of a Pliocene tidal clay deposit at
Grobbendonk (Antwerp Province, Belgium). Geologica Belgica, 3/3-4, 405-417. https://doi.org/10.20341/gb.2014.040

Vandenberghe, N., Van Simaeys, S., Steurbaut, E., Jagt, J.W.M. \& Felder, P.J., 2004. Stratigraphic architecture of the Upper Cretaceous and Cenozoic along the southern border of the North Sea Basin in Belgium. Netherlands Journal of Geosciences / Geologie en Mijnbouw, 83/3, 155-171. https://doi.org/10.1017/ S0016774600020229

Vandenberghe, N., Laga, P., Louwye, S., Vanhoorne, R., Marquet, R., De Meuter F., Wouters, K., Hagemann, H.W., 2005. Stratigraphic interpretation of the Neogene marine-continental record in the Maaseik well (49W0220) in the Roer valley Graben, NE Belgium. Memoirs of the Geological Survey of Belgium, 52, $39 \mathrm{p}$.

Vandenberghe, N., Wouters, L., Schiltz, M., Beerten, K., Berwouts, I., Vos, K., Houthuys, R., Deckers, J., Louwye, S., Laga, P., Verhaegen, J., Adriaens, R. \& Dusar, M., 2020. The Kasterlee Formation and its relation with the Diest and Mol Formations in the Belgian Campine. Geologica Belgica, 23/3-4, this volume. https:// doi.org/10.20341/gb.2020.014

Vanden Broeck, E. \& Cogels, O., 1877. Observations sur les couches quaternaires et pliocènes de Merxem. Annales de la Société malacologique de Belgique, Bulletins, 12, 68-74.

Van Haren, T., Deckers, J., De Koninck, R., Dirix, K., Hambsch, L. \& Van Baelen, K., in prep. Ondiep geologische 3D lagen- en voxelmodel van de regio Antwerpen. VITO, Mol, VITO-rapport 2019/RMA/R/1985.

Vanhoorne, R., 1962. La superposition des Sables de Mol et des Argiles de Campine. Mémoires de la Société belge de Géologie, de Paléontologie et d'Hydrologie, série in- $8^{\circ}, 6,83-95$.

Vanhoorne, R., 1973. The continental Pleistocene in Belgium. Proceedings of the III International palynological conference. Academy of Sciences of the USSR, Institute of Geography, Nauka, Moscow, 175-178

van Loon, A.J., 2009. Unravelling the enigmas of the 'silver sands' in the Dutch/German/Belgian border area. Netherlands Journal of Geosciences / Geologie en Mijnbouw, 88/3, 133-345. https:// doi.org/10.1017/S0016774600000858

Van Tassel, R., 1964a. Merkwaardige konkreties in de pleistocene mariene afzettingen van Antwerpen. KVIV- De geologie van het havengebied van Antwerpen. Verslagboek Vierde Internationaal Havenkongres Antwerpen 22-27 juni 1964, 7-8.

Van Tassel, R., 1964b. Concrétions tubulées du Merksemien (Pléistocène inférieur), à Anvers. Bulletin de la Société belge de Géologie, de Paléontologie et d'Hydrologie, 73, 469-497.

Verhaegen, J., 2020. Stratigraphic discriminatory potential of heavy mineral analysis for the Neogene sediments of Belgium. Geologica Belgica, 23/3-4, this volume. https://doi.org/10.20341/gb.2020.003

Vincent, G., 1889. Documents relatifs aux sables pliocènes à Chrysodomus contraria. Annales de la Société malacologique de Belgique, Bulletins, 24, 25-31.

Vinken, R. (ed.), 1988. The Northwest European Tertiary Basin. Geologisches Jahrbuch, Reihe A, 100, 508 p.

Vos, K., 2018. A generic prospection strategy for industrial sands with high resistance to compressive stress. Unpublished Ph.D. Thesis, Geology, KU Leuven, Leuven, 280 p.

Wesselingh, F.P., Busschers, F. \& Goolaerts, S., 2020. Observations on the Pliocene sediments exposed at Antwerpen International Airport (northern Belgium) constrain the stratigraphic position of the Broechem fauna. Geologica Belgica, 23/3-4, this volume. https:// doi.org/10.20341/gb.2020.026

Westerhoff, W.E., 2009. Stratigraphy and sedimentary evolution: The lower Rhine-Meuse system during the Late Pliocene and Early Pleistocene (southern North Sea Basin). Ph.D. Thesis, Vrije Universiteit Amsterdam, Amsterdam, $168 \mathrm{p}$.

Willems, W., Laga, P. \& Moorkens, T., 1988. Benthic foraminifera Belgium. In Vinken, R. (ed.), The Northwest European Tertiary Basin. Geologisches Jahrbuch, Reihe A, 100, 179-188.

Wong, T., de Lugt, I., Kuhlmann, G. \& Overeem, I., 2007. Tertiary. In Wong, T., Batjes, D. \& de Jager, J. (eds), Geology of the Netherlands. Royal Netherlands Academy of Arts and Sciences, Amsterdam, 151-171.

Ziegler, P.A., 1990. Geological Atlas of Western and Central Europe $2^{\text {nd }}$ ed. Shell Internationale Petroleum Maatschappij, The Hague, and Geological Society, London, 239 p.

Manuscript received 06.11.2020, accepted in revised form 15.12.2020, available online 30.12.2020. 